Article

\title{
The Impact of COVID-19 Lockdowns on Air Quality-A Global Review
}

\author{
Abdullah Addas*(D) and Ahmad Maghrabi \\ Landscape Architecture Department, Faculty of Architecture and Planning, King Abdulaziz University, \\ P.O. Box 80210, Jeddah 21589, Saudi Arabia; aamaghrabi@kau.edu.sa \\ * Correspondence: aaddas@kau.edu.sa
}

Citation: Addas, A.; Maghrabi, A. The Impact of COVID-19 Lockdowns on Air Quality-A Global Review. Sustainability 2021, 13, 10212. https:/ / doi.org/10.3390/su131810212

Academic Editor:

Samuel Asumadu-Sarkodie

Received: 27 July 2021

Accepted: 9 September 2021

Published: 13 September 2021

Publisher's Note: MDPI stays neutral with regard to jurisdictional claims in published maps and institutional affiliations.

Copyright: (c) 2021 by the authors. Licensee MDPI, Basel, Switzerland. This article is an open access article distributed under the terms and conditions of the Creative Commons Attribution (CC BY) license (https:// creativecommons.org/licenses/by/ $4.0 /)$.

\begin{abstract}
The outbreak of the COVID-19 pandemic has emerged as a serious public health threat and has had a tremendous impact on all spheres of the environment. The air quality across the world improved because of COVID-19 lockdowns. Since the outbreak of COVID-19, large numbers of studies have been carried out on the impact of lockdowns on air quality around the world, but no studies have been carried out on the systematic review on the impact of lockdowns on air quality. This study aims to systematically assess the bibliographic review on the impact of lockdowns on air quality around the globe. A total of 237 studies were identified after rigorous review, and 144 studies met the criteria for the review. The literature was surveyed from Scopus, Google Scholar, PubMed, Web of Science, and the Google search engine. The results reveal that (i) most of the studies were carried out on Asia (about 65\%), followed by Europe (18\%), North America (6\%), South America (5\%), and Africa (3\%); (ii) in the case of countries, the highest number of studies was performed on India $(29 \%)$, followed by China (23\%), the U.S. (5\%), the UK (4\%), and Italy; (iii) more than $60 \%$ of the studies included $\mathrm{NO}_{2}$ for study, followed by $\mathrm{PM}_{2.5}$ (about 50\%), $\mathrm{PM}_{10}, \mathrm{SO}_{2}$, and CO; (iv) most of the studies were published by Science of the Total Environment (29\%), followed by Aerosol and Air Quality Research (23\%), Air Quality, Atmosphere E Health (9\%), and Environmental Pollution (5\%); (v) the studies reveal that there were significant improvements in air quality during lockdowns in comparison with previous time periods. Thus, this diversified study conducted on the impact of lockdowns on air quality will surely assist in identifying any gaps, as it outlines the insights of the current scientific research.
\end{abstract}

Keywords: COVID-19; air quality; lockdown; public health; Science of the Total Environment; scientific research

\section{Introduction}

The novel coronavirus (SARS-CoV-2) originated from Wuhan in December 2019, and later spread to many countries across the world [1]. The World Health Organization (WHO) declared this virus a "global pandemic" on 11 March 2020. In many parts of the world, severely affected countries imposed lockdowns to prevent the transmission of COVID-19 by restricting transportation, economic, and industrial activities. Thus, restrictions on human activities and the various productive activities of industries and farms resulted in unforeseen impacts and improved the health of the environment to a great extent. The air quality also significantly improved across the globe because of the restricted emissions from different sources during lockdowns. In many previous research studies, it is welldocumented that many countries of the world are facing serious public health problems due to extreme air pollution [2-5]. More than $60 \%$ of the populations living in urban areas are severely exposed to the serious problem of air pollution [1]. Both high-income (56\%) and low-income $(98 \%)$ countries of the world fail to meet the guidelines proposed by WHO [1] As per the reports published by WHO [1], more than 4.2 billion people have lost their lives because of health risks related to air pollution [1]. Air pollution has become one of the most significant health risks [6-9] and results in great loss of life. According to an estimation 
by the Global Burden of Disease Project of the WHO, 1.1 million premature deaths were reported in 2016 primarily because of outdoor particulate matter $\left(\mathrm{PM}_{2.5}\right)$ pollution [10]. The WHO [1] recently released a report from the Global Ambient Air Quality Database on the concentration of $\mathrm{PM}_{2.5}$ across 100 countries of the world and it was observed that the concentration of $\mathrm{PM}_{2.5}$ was relatively higher across the cities of developing countries, such as India, Bangladesh, Pakistan, the Middle East, Afghanistan, and Mongolia. Developing cities, such as Delhi (India), Dhaka (Bangladesh), Kabul (Afghanistan), Manama (Bahrain), and Beijing (China) are vulnerable to extreme air pollution.

The recent outbreak of COVID-19 has had an immense impact on air quality across the world [11-15]. After the outbreak of COVID-19, a large number of studies were performed on the impact of lockdowns on air quality [16-18]. The concentration of major air pollutants, such as $\mathrm{PM}_{2.5}, \mathrm{PM}_{10}, \mathrm{SO}_{2}, \mathrm{CO}$, and $\mathrm{NO}_{2}$, were reduced by about $30 \%$ because of lockdowns [19]. Similar studies were conducted in Spain [20], Italy [21], Brazil [22], (Morocco [23], India [24], the U.S. [25], and Bangladesh [26]. All the studies concluded that there was a significant reduction in air pollutants, and a significant improvement in air quality during lockdown due to COVID-19.

According to Muhammad et al. [27], there were substantial decreases in fuel demand around the world during lockdown periods due to the cessation of transportation and industrial activities. The reduced demand for fuel resulted in the drastic reduction of carbon emissions and air pollutant concentrations [15-17,28,29]. To the best of our knowledge, there have been no review studies performed on the impact of lockdowns on air quality across the globe until now. Considering this research gap, this study aims to assess a review on the impact of lockdown on air quality across the world. This study includes more than 40 countries across the world from six continents, and more than 140 research studies. This is the first attempt at dealing with the assessment of a systematic review on the impact of COVID-19 lockdowns on air quality on a global scale. The findings of this study could help planners and policymakers understand, as well as implement, effective strategies for the reduction of air pollution levels at the city, regional, and country scales.

\section{Materials and Methods}

At the beginning of the study, a total of 237 research studies were searched using keywords. From the 237 research studies, 144 research papers were finally selected on the basis of two criteria. In the initial stages, the studies were shortlisted through the screening of the abstracts and titles of the papers. At the second stage of the literature screening, the articles were selected on the basis of the scales of the studies (the city, regional, and country scales). Thus, 144 articles were finally included in this literature screening. Before the final selection of studies for this review assessment, some criteria were set. First, the studies performed on the impact of lockdowns on the air quality at the city, regional, and country scales were included in this review process. Secondly, the literature screening was carried out from March 2020 to April 2021, and no studies published after April 2021 were considered. Thirdly, the studies performed on multiple countries, or cities from multiple countries, were not considered for the review process. The details of the literature screening procedures are presented in Figure 1. Previous literature was considered on the basis of the objectives of the study (Tables 1 and 2), i.e., studies performed on the impact of lockdowns on the air quality at the city, regional and country scales, respectively. The entire process of the literature screening is shown through a PRISMA flow diagram [30] (Figure 2).

\section{Keywords for Search of Academic Databases}

The main objective of this study was to examine the impact of COVID-19 lockdowns on air quality. Thus, keywords, such as "air pollution", "air quality", "lockdown", "COVID-19", and "pandemic" were used. The main databases searched were Scopus, Web of Science, Science Direct, Google Scholar, PubMed, and the Google search engine. The majority of the articles were searched from Google Scholar, followed by Scopus, Web of Science, and the Google search Engine, from March 2020 to April 2021 (Figure 1). 


\begin{tabular}{l}
\hline Study outcomes \\
The expected outcomes \\
of this present study is \\
to explore the reviews \\
and to analyze the \\
impact of COVID-19 \\
amid lockdown on air \\
quality across the \\
globe.
\end{tabular}

\begin{tabular}{|l|}
\hline \multicolumn{2}{|c|}{ Study strategies } \\
\hline For searching the \\
relevant literatures, \\
related to air quality, \\
lockdown, COVID-19, \\
developing countries \\
etc. were used. The \\
relevant literatures \\
were extracted from \\
Scopus, Web of \\
Science, Science Direct, \\
Google Scholar, \\
PubMed and Google \\
Search Engine \\
respectively.
\end{tabular}

\section{Exclusion}

1. Studies performed after April 2021 were not considered.

2. Studies performed on multiple countries or

cities form multiple countries were not considered.

3. Literatures not in English were not considered.

Figure 1. Details of the methodology used in this literature review.

Table 1. Distribution of literature across major continents (until April 2021).

\begin{tabular}{|c|c|c|}
\hline Continents & Country & Number of Studies \\
\hline Europe (33) & $\begin{array}{c}\text { UK (8), Turkey (3), France (2), Spain (6), Italy (7), Germany } \\
\text { (1), Poland (1), Netherland (1), Portugal (1), Russia (1), } \\
\text { Macedonia (1), Albania (1). }\end{array}$ & 33 \\
\hline North and South America (20) & $\begin{array}{l}\text { USA (9), Canada (1), Ecuador (4), Brazil (4), Mexico (2), } \\
\text { India (53), China (42), Thailand (2), Bangladesh (5), }\end{array}$ & 20 \\
\hline Asia (117) & $\begin{array}{c}\text { Malaysia (2), Singapore (1), Iran (1), Israel (1), Japan (1), } \\
\text { Pakistan (3), Vietnam (1), Korea (3), Kazakhstan (1), Saudi } \\
\text { Arabia (1) }\end{array}$ & 117 \\
\hline Oceania (2) & Australia (2) & 2 \\
\hline Africa (7) & Nigeria (1), Morocco (3), Egypt (2), Uganda (1) & $\overline{7}$ \\
\hline
\end{tabular}

Table 2. Country-wide distribution of the literature across the world.

\begin{tabular}{cccc}
\hline Continent & Country & Number of Studies & \% of Studies \\
\hline India & 53 & 29.44 \\
China & 42 & 23.33 \\
Bangladesh & 5 & 2.78 \\
Thailand & 2 & 1.11 \\
Pakistan & 3 & 1.67 \\
Malaysia & 2 & 1.11 \\
Korea & 3 & 1.67 \\
Asia & 1 & 0.56 \\
& Israel & 1 & 0.56 \\
& Iran & 1 & 0.56 \\
& Vietnam & 1 & 0.56 \\
& Kazakhstan & 1 & 0.56 \\
& Saudi Arabia & 8 & 4.44 \\
UK & 6 & 3.33 \\
& Spain & 7 & 3.89 \\
\hline
\end{tabular}


Table 2. Cont.

\begin{tabular}{cccc}
\hline Continent & Country & Number of Studies & \% of Studies \\
\hline \multirow{5}{*}{ Asia } & Turkey & 3 & 1.67 \\
& Russia & 1 & 0.56 \\
& Germany & 1 & 0.56 \\
& Macedonia & 1 & 0.56 \\
& Albania & 1 & 0.56 \\
& Portugal & 1 & 0.56 \\
& Netherlands & 1 & 0.56 \\
& Poland & 1 & 0.56 \\
& Serbia & 1 & 0.56 \\
North America & France & 2 & 1.11 \\
\hline \multirow{3}{*}{ Africa } & US & 9 & 5.00 \\
& Canada & 1 & 0.56 \\
\hline \multirow{2}{*}{ South America } & Morocco & 3 & 1.67 \\
& Egypt & 2 & 1.11 \\
& Kampala & 1 & 0.56 \\
& Nigeria & 1 & 0.56 \\
\hline Oceania & Brazil & 4 & 2.22 \\
& Ecuador & 4 & 2.22 \\
& Mexico & 2 & 1.11 \\
\hline
\end{tabular}
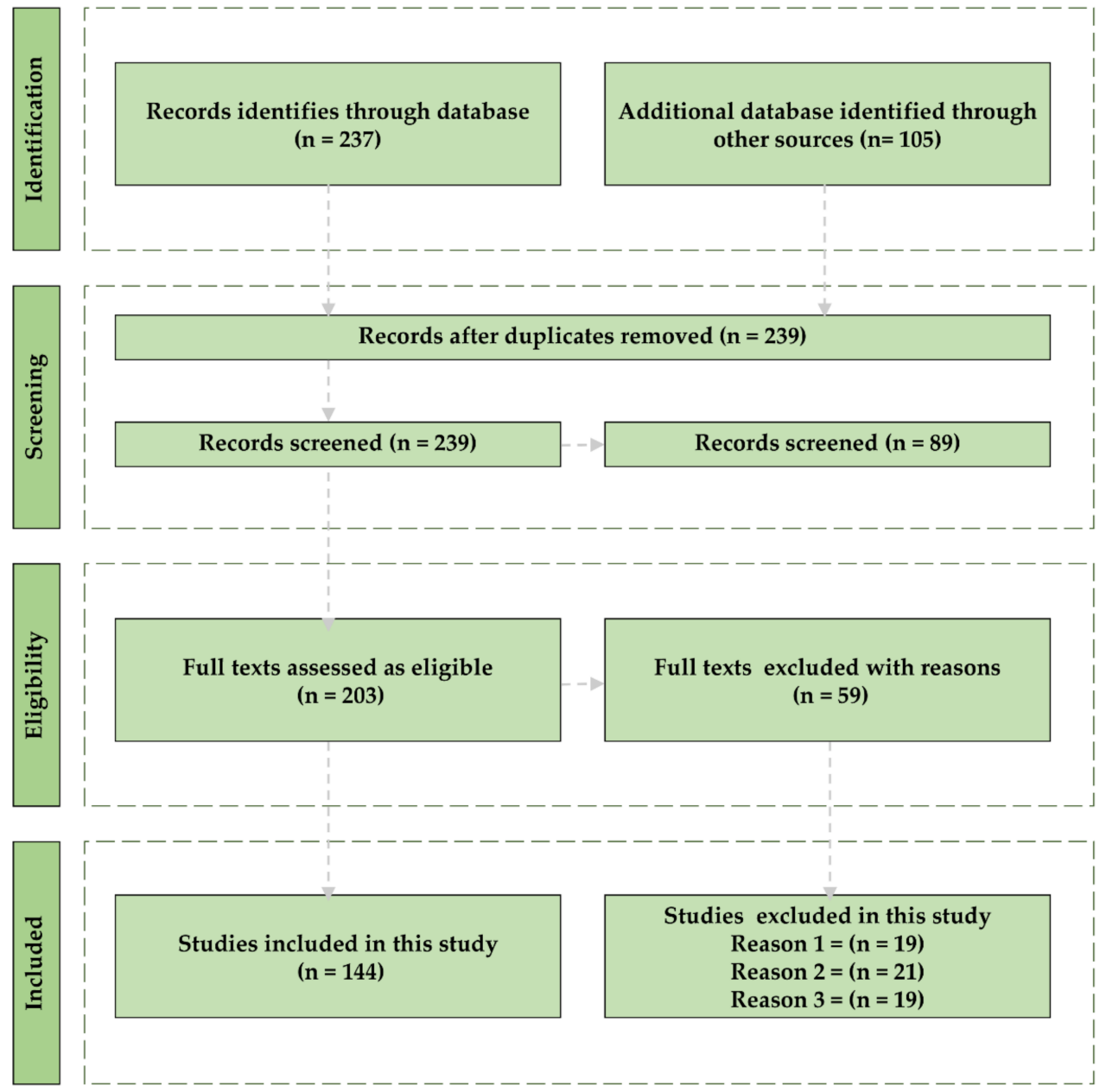

Figure 2. PRISMA flow diagram showing procedure used for systematic review. 


\section{Results}

\subsection{Geographical Distribution and COVID-19 Studies}

In the present analysis, about $70 \%$ of the total papers were published in 2020 (particularly from March to December) and the rest of the papers were published (30\%) in 2021 (considered up to the month of April). This study encompasses five continents: Asia, Europe, Africa, North America, and South America. About 65\% of the total studies were surveyed from Asia, followed by Europe (18\%), Africa (7\%), North America (6\%), South America (6\%), and Australia (1\%). In the case of countries, the highest number of studies were surveyed from India (29\%), followed by China (23\%), the U.S. (6\%), the UK (5\%), Italy $(3.8 \%)$, and Bangladesh (2.78\%) (Figure 3$)$.

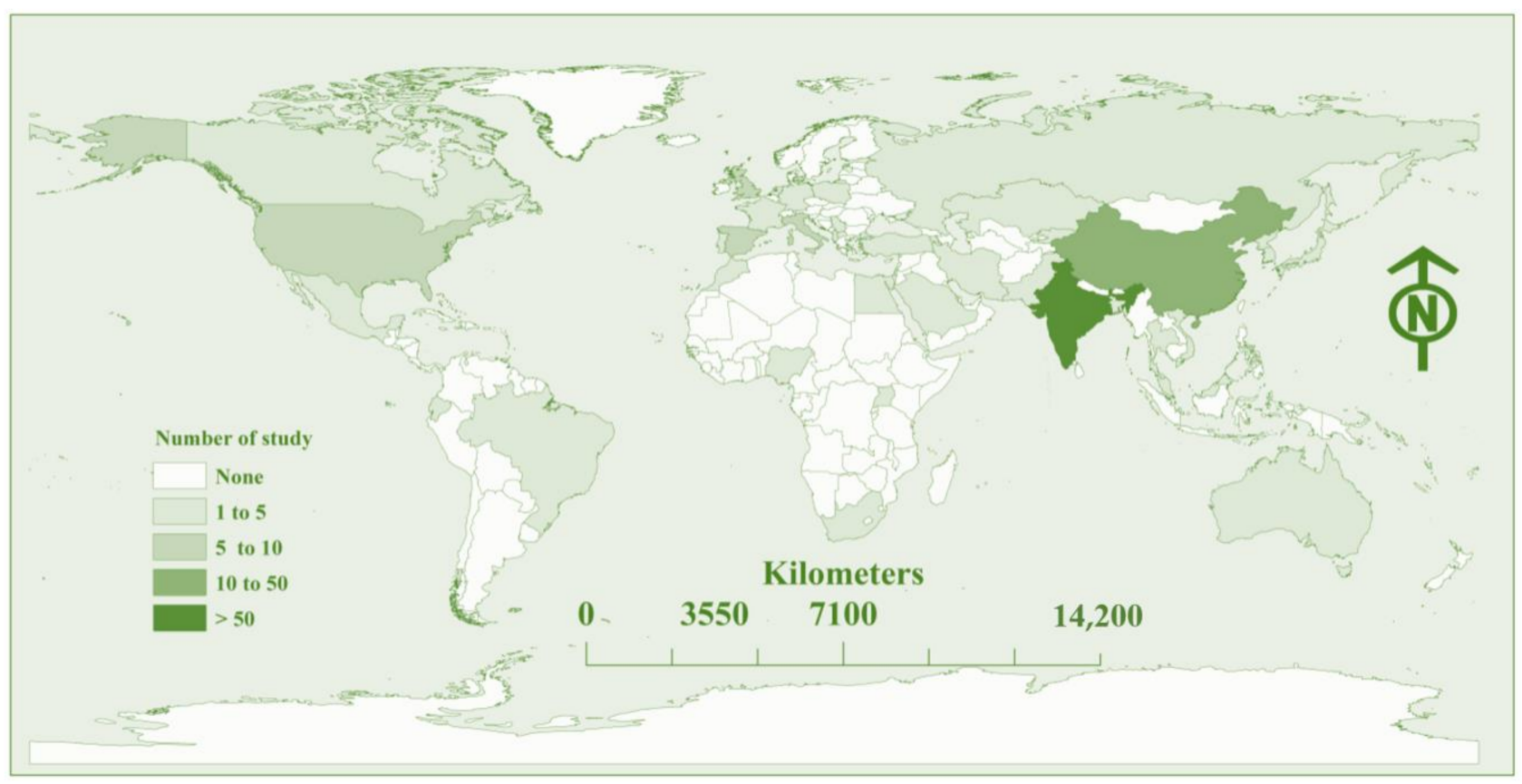

Figure 3. Global scenario of air quality studies (from March 2020 to April 2021).

\subsection{Impact of COVID-19 on Air Quality over Asian Countries}

From the overall studies surveyed, it was observed that the greatest number of studies on the impact of the COVID-19 pandemic on air quality was performed on Asian countries (65\%). As per our literature survey, it is documented that about $45 \%$ of the research studies on the impact of COVID-19 on air quality was identified from India, followed by China (36\%), Bangladesh (4\%), Pakistan (2.6), Korea (2.6\%), and Thailand (1.7\%). In India, most of the studies were performed on polluted cities and large megacities, such as Delhi, Mumbai, Kolkata, Chennai, Bengaluru, Varanasi, Patna, Gaya, Hyderabad, and Pune. About $60 \%$ of the studies were performed over the megacity, Delhi (the capital city of India). In China, most of the studies were performed on large cities, such as Wuhan, Beijing, the megacity Hangzhou, Anqing, Hefei, and the city of Suzhou (Table 3). The studies focusing on the concentrations of $\mathrm{PM}_{2.5}$ are shown in Figure 4. 
Table 3. Literature on the impact of COVID-19 on air quality in Asian countries. respectively, in comparison to 2019 [18].

\begin{tabular}{|c|c|c|}
\hline Country & 2020 & $\begin{array}{l}\text { There was a remarkable decline in the ambient air quality index (AQI) (17.75\% and } 20.70 \% \text {, respectively) during } \\
\text { post-lockdown periods as compared to pre-lockdown periods (ii) poor air quality had a positive correlation with } \\
\text { COVID-19 mortalities ( } \mathrm{r}=0.435 \text { for AQI) [31]. }\end{array}$ \\
\hline State & 2020 & $\begin{array}{l}\text { There was a substantial reduction in air pollutants during different phases of lockdowns (ii) } \mathrm{PM}_{2.5} \text { and } \mathrm{PM}_{10} \\
\text { decreased by about } 17.76 \% \text { and } 20.66 \% \text {, respectively, during consecutive periods of lockdowns [32]. }\end{array}$ \\
\hline City scale & 2021 & $\mathrm{PM}_{2.5}$ was reduced by about 40 to $45 \%$ during lockdown periods in comparison to the previous two years [33]. \\
\hline City scale & 2020 & Particulate matter concentration decreased by about $40 \%$ during lockdown in comparison to previous years [34]. \\
\hline City scale & 2020 & $\begin{array}{l}\text { The lockdown measures reflected a significant reduction in air pollutants; the most significant fall was estimated } \\
\text { for } \mathrm{NO}_{2}(29.3-74.4 \%) \text {, while the least reduction was noticed for } \mathrm{SO}_{2}[35] .\end{array}$ \\
\hline City scale & 2020 & $\begin{array}{c}\text { The average value of AQI at Punjab Bagh was noticed as } 212 \text { before the lockdown, which dropped down to } 74 \\
\text { during the lockdown, indicating a significant improvement in air quality [23]. }\end{array}$ \\
\hline City scale & 2020 & $\begin{array}{c}\text { The results indicate the lowering of } \mathrm{PM}_{2.5}, \mathrm{PM}_{10} \text {, and } \mathrm{NO}_{2} \text { concentrations in the city by } 93 \%, 83 \% \text {, and } 70 \% \text {, } \\
\text { respectively, from } 25 \text { February } 2020 \text { to } 21 \text { April } 2020 \text { [17]. }\end{array}$ \\
\hline City scale & 2020 & The concentration of $\mathrm{NO}_{2}$ and $\mathrm{PM}_{2.5}$ significantly decreased due to lockdowns across cities [36]. \\
\hline City scale & 2020 & $\begin{array}{l}\text { These two cities observed a substantial decrease in nitrogen dioxide }(40-50 \%) \text { compared to the same period last } \\
\text { year [37]. }\end{array}$ \\
\hline City scale & 2020 & $\begin{array}{l}\text { Major negative effects on the social and surrounding environment have been reported due to COVID-19, however } \\
\text { positive effects have also been observed with respect to air quality. The results have been taken from the National } \\
\text { Aeronautics and Space Administration (NASA), and indicate a significant reduction (50\%) in the air quality of the } \\
\text { Indian region [23]. }\end{array}$ \\
\hline City Scale & 2020 & $\begin{array}{l}\text { A considerable reduction }(\sim 30-70 \%) \text { in } \mathrm{NO}_{2} \text { was found, except for a few sites in the central region. A similar } \\
\text { pattern was observed for } \mathrm{CO} \text { having a } \sim 20-40 \% \text { reduction. The reduction observed for } \mathrm{PM}_{2.5}, \mathrm{PM}_{10}, \mathrm{NO}_{2} \text {, and the } \\
\text { enhancement in } \mathrm{O}_{3} \text { was proportional to the population density [38]. }\end{array}$ \\
\hline
\end{tabular}


Table 3. Cont.

$\mathrm{PM}_{2.5}$ has declined by $14 \%$, by about $30 \%$ for $\mathrm{NO}_{2}$ in million-plus cities, and a $2.06 \% \mathrm{CO}, \mathrm{SO}_{2}$ within the range of 5 to $60 \%$, whereas the concentration of $\mathrm{O}_{3}$ has increased by 1 to $3 \%$ in the majority of cities compared with

City scale

decrease in $\mathrm{PM}_{10}$ in north Indian cities, more than a $35 \%$ decrease in $\mathrm{NO}_{2}$ in metropolitan cities, more than an $85 \%$ decrease in $\mathrm{SO}_{2}$ in Chennai and Nagpur, and a more than $17 \%$ increase in $\mathrm{O}_{3}$ in five cities during 43 days of pandemic lockdown [39].

\begin{tabular}{|c|c|c|}
\hline & & \\
\hline City scale & 2020 & $\begin{array}{l}\text { The lockdown effect due to COVID-19 in the city: the complete closure of industries, transports, markets, shopping } \\
\text { malls, recreation units, construction works, etc., which are the main sources of } \mathrm{CO}_{2} \text { emissions [40]. }\end{array}$ \\
\hline City scale & 2021 & $\begin{array}{c}\text { Highest levels of } \mathrm{PM}_{10} \text { and } \mathrm{PM}_{2.5} \text { were observed near sunrise, with little change in the time of maximum levels } \\
\text { between } 2019 \text { and } 2020 \text { [41]. }\end{array}$ \\
\hline City scale & 2020 & $\begin{array}{l}\text { A reduction of almost } 60 \% \text { in the particulate matter pollution, and up to } 40 \% \text { in the } \mathrm{NO}_{\mathrm{x}} \text { pollution, were observed, } \\
\text { while the ozone levels were reduced by } 30-40 \% \text {, as compared to the same period during the previous two years } \\
\text { [42]. }\end{array}$ \\
\hline City scale & 2021 & $\begin{array}{l}\text { The air quality has improved across the country and the average temperature and maximum temperature were } \\
\text { connected to the outbreak of the COVID-19 pandemic [43]. }\end{array}$ \\
\hline City scale & 2020 & Before 30 days of lockdown, $\mathrm{PM}_{2.5}$ was $65.77 \mu \mathrm{g} / \mathrm{m}^{3}$ and that reached $42.72 \mu \mathrm{g} / \mathrm{m}^{3}$ during lockdown periods [44]. \\
\hline City scale & $2021(a)$ & $\begin{array}{l}\text { During lockdown, maximum decrease was reported for } \mathrm{NO}_{2}(40 \%) \text {, followed by } \mathrm{PM}_{2.5}(32 \%), \mathrm{PM}_{10}(24 \%) \text {, and } \mathrm{SO}_{2} \\
(18 \%)[45] .\end{array}$ \\
\hline City scale & $2021(b)$ & During entire periods of lockdown, the average concentration of $\mathrm{PM}_{2.5}$ declined by $50 \%$ [46]. \\
\hline City scale & 2020 & $\begin{array}{c}\text { Suspended particulate matter (SPM) was reduced by about } 36 \% \text {. The concentration of } \mathrm{NO}_{2} \text { was also reduced } \\
\text { during lockdown periods [46]. }\end{array}$ \\
\hline City & 2020 & $\begin{array}{l}\text { The concentration of } \mathrm{PM}_{2.5}, \mathrm{PM}_{10} \text {, and } \mathrm{NO}_{2} \text { declined by about } 50 \% \text {, with a significant increase in } \mathrm{O}_{3} \text { in Delhi } \\
\qquad(p<0.05) \text { [35]. }\end{array}$ \\
\hline Country & 2021 & $\begin{array}{l}\text { Over the urban agglomerations (UAs), and rural regions, the concentrations of } \mathrm{NO}_{2} \text { were reduced by about } 20-40 \% \\
\text { and } 15-25 \% \text {, respectively [47]. }\end{array}$ \\
\hline Regional & 2020 & $\begin{array}{c}\text { Mumbai recorded the highest decrease of } \mathrm{NO}_{2}(34 \%) \text { with a seasonal decrease of } \mathrm{SO}_{2} \text { in western and southern } \\
\text { India [48]. }\end{array}$ \\
\hline City & 2021 & $\begin{array}{l}\text { During lockdown periods, the concentration of } \mathrm{PM}_{2.5} \text { and } \mathrm{PM}_{10} \text { declined by about } 43 \% \text { and } 59 \% \text {, respectively, in } \\
\text { Delhi, and by } 50 \% \text { and } 49 \% \text {, respectively, in Kolkata [49]. }\end{array}$ \\
\hline City & 2020 & $\begin{array}{l}\text { During the initial periods of lockdown, the concentration of } \mathrm{PM}_{2.5} \text { declined by about } 40 \text { to } 70 \% \text { (from } 25 \text { March to } \\
31 \text { March 2020) [50]. }\end{array}$ \\
\hline
\end{tabular}


Table 3. Cont

\begin{tabular}{|c|c|c|c|}
\hline Country & Study Area & Publication Year & Major Findings \\
\hline \multirow{14}{*}{ India } & City & 2020 & $\begin{array}{l}\text { From } 11 \text { May to } 9 \text { June 2020, the concentrations of } \mathrm{PM}_{2.5}, \mathrm{PM}_{10} \text {, and } \mathrm{NO}_{2} \text { were reduced by about } 74 \%, 46 \% \text {, and } \\
63 \% \text {, respectively [51]. }\end{array}$ \\
\hline & City & 2020 & $\begin{array}{c}\text { There was a substantial decrease in } \mathrm{PM}_{2.5}, \mathrm{PM}_{10} \text {, and } \mathrm{NO}_{2} \text { during lockdown, with the highest decline in } \\
\text { Ahmedabad (68\%), Delhi (71\%), Bangalore (87\%), and Nagpur (63\%), for } \mathrm{PM}_{2.5}, \mathrm{PM}_{10}, \mathrm{NO}_{2} \text { and } \mathrm{CO} \text {, } \\
\text { respectively [16]. }\end{array}$ \\
\hline & City & 2020 & $\mathrm{NO}_{2}$ was reduced by about $46 \%$ and the air quality index (AQI) improved by about $27 \%$ [52]. \\
\hline & City & 2020 & $\begin{array}{l}\text { Air quality index (AQI) was reduced by } 44,33,29,15 \text {, and } 32 \% \text { in north, south, east, central and western India. The } \\
\text { highest decrease was reported for } \mathrm{PM}_{2.5}(43 \%) \text {, followed } \mathrm{PM}_{10}(33 \%), \mathrm{NO}_{2}(18 \%) \text {, and } \mathrm{CO}(10 \%)[53] \text {. }\end{array}$ \\
\hline & City & 2020 & Air pollutants $\left(\mathrm{PM}_{2.5}, \mathrm{PM}_{10}, \mathrm{NO}_{2}\right.$, and $\left.\mathrm{CO}\right)$ were reduced by about $50 \%$ across the megacities of India [54]. \\
\hline & City & 2020 & $\begin{array}{c}\text { The concentration of } \mathrm{PM}_{2.5} \text { was reduced by about } 19 \text { to } 43 \% \text { in Chennai, } 41 \text { to } 53 \% \text { in Delhi, } 26 \text { to } 54 \% \text { in } \\
\text { Hyderabad, } 24 \text { to } 36 \% \text { in Kolkata, and } 10 \text { to } 39 \% \text { in Mumbai [55]. }\end{array}$ \\
\hline & City & 2020 & $\begin{array}{l}\text { The concentrations of } \mathrm{PM}_{2.5}, \mathrm{PM}_{10}, \mathrm{NO}_{2} \text { and } \mathrm{SO}_{2} \text { were } 49,55,60 \text { and } 19 \% \text {, respectively, in Delhi, and 44, 37, } 78 \text {, and } \\
39 \% \text {, respectively, in Mumbai [56]. }\end{array}$ \\
\hline & City & 2020 & $\mathrm{PM}_{10}$ was reduced by more than $46 \%$ across five cities [57]. \\
\hline & City & 2021 & $\begin{array}{c}\text { The concentrations of } \mathrm{PM}_{10}, \mathrm{PM}_{2.5}, \mathrm{NO}_{\mathrm{x}}, \mathrm{SO}_{2} \text {, and } \mathrm{CO} \text { were reduced by about } 58,47,83,11 \text {, and } 30 \% \text {, } \\
\text { respectively [59]. }\end{array}$ \\
\hline & City & 2020 & The concentration of $\mathrm{PM}_{2.5}$ decreased from $72.9 \mu \mathrm{g} \mathrm{m}{ }^{-3}$ (2019) to $45.9 \mu \mathrm{g} \mathrm{m}^{-3}$ (2020) during lockdown periods [60]. \\
\hline & City scale & 2020 & The concentrations of $\mathrm{PM}_{2.5}, \mathrm{PM}_{10}, \mathrm{SO}_{2}, \mathrm{CO}_{2}$, and $\mathrm{NO}_{2}$ decreased due to lockdown [17]. \\
\hline & Country and City scale & 2020 & Air quality improved by about $25 \%$ during lockdown periods [61]. \\
\hline & City scale & 2020 & $\begin{array}{l}\text { The over-standard multiples method and a grey relational analysis to study the individual and overall change } \\
\text { trends of pollutants in } \mathrm{Wuhan}^{-} \text {during the same period in the past seven years. The results show that the } \\
\text { concentrations of } \mathrm{SO}_{2} \text { and } \mathrm{O}_{3} \text { increased because of the pandemic, but still met the standard [62]. }\end{array}$ \\
\hline & City Scale & 2020 & $\begin{array}{l}\text { Urban aerosols decreased from } 27.1 \% \text { for pre-C19Q aerosols to only } 17.5 \% \text { during C19Q. WRF-Chem reported a } \\
\sim 0.2^{\circ} \mathrm{C} \text { warming across east-central China that represented a minor, though statistically significant, contribution to } \\
\mathrm{C} 19 \mathrm{Q} \text { temperature anomalies. The largest area of warming is concentrated south of Chengdu and Wuhan, where } \\
\text { temperatures increased between }+0.2-0.3^{\circ} \mathrm{C} \text { [63]. }\end{array}$ \\
\hline
\end{tabular}


Table 3. Cont

The increment in secondary organic and inorganic aerosols under stationary weather reached up to $36.4 \%$ and $10.2 \%$, respectively, which was further intensified by regional transport. PRD was quite the opposite. The emission

City scale

reductions benefited PRD air quality, while regional transport corresponded to an increase of $17.3 \%$ and $9.3 \%$ in secondary organic and inorganic aerosols, respectively. In different regions, the maximum daily $8 \mathrm{~h}$ average ozone $\left(\mathrm{O}_{3}\right)$ soared by $20.6-76.8 \%$ in YRD but decreased by $15.5-28.1 \%$ in PRD. In YRD, nitrogen oxide $\left(\mathrm{NO}_{\mathrm{x}}\right)$ reductions enhanced $\mathrm{O}_{3}$ accumulation and, hence, increased secondary aerosol formation [64].

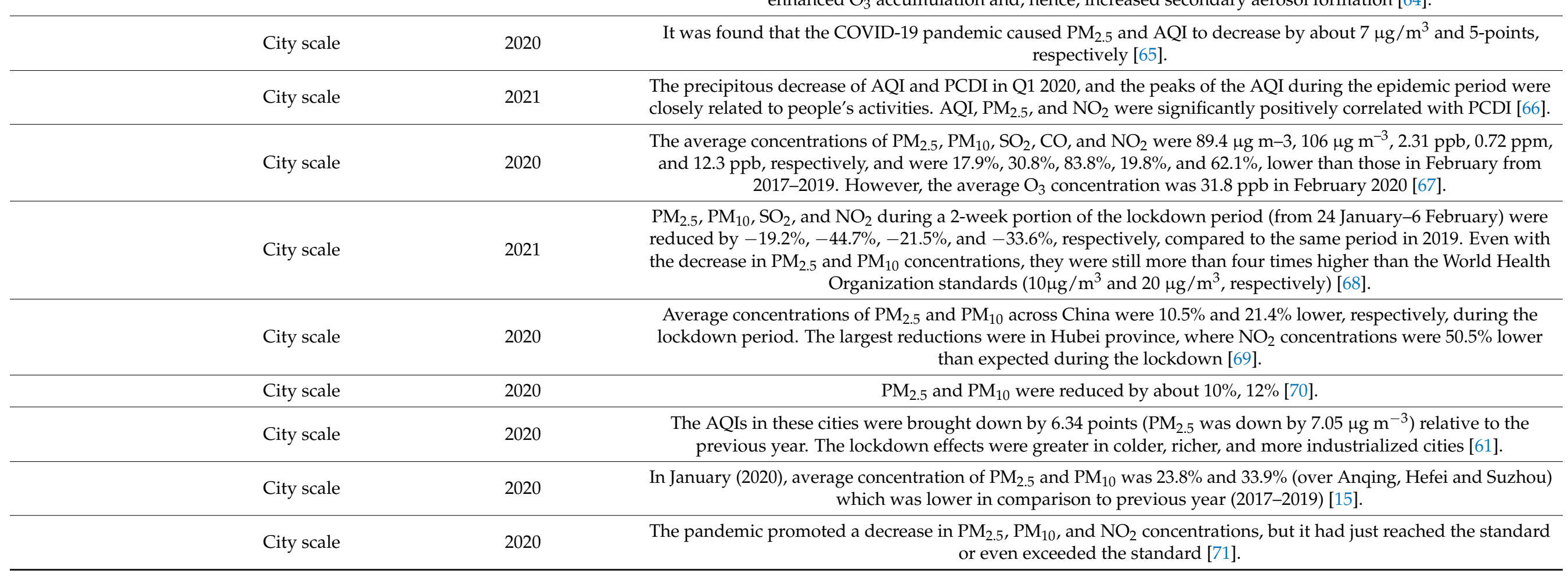


Table 3. Cont.

\section{Major Findings}

City scale

2020

The concentrations of $\mathrm{SO}_{2}$ and $\mathrm{O}_{3}$ increased but still met the standard. However, the pandemic promoted a decrease in $\mathrm{PM}_{2.5}, \mathrm{PM}_{10}$, and $\mathrm{NO}_{2}$ concentrations, but it had just reached the standard or even exceeded the standard [62].

\begin{tabular}{crc}
\hline Country and City scale & 2020 & $\mathrm{O}_{3}$ responses to $\mathrm{NO}_{2}$ declines can be affected by the primary dependence on its precursors [72]. \\
\hline City scale & 2021 & $\begin{array}{c}\text { The air quality index (AQI) during the lockdown period decreased by 7.4\%, and by 23.48\%, compared to } \\
\text { pre-lockdown levels and the identical lunar period during the past 3 years, respectively, which exhibited optimal } \\
\text { air quality due to reduced emissions [73]. }\end{array}$ \\
\hline
\end{tabular}

City scale

2020

City scale

2021

China

\begin{tabular}{|c|c|c|}
\hline Country & 2020 & The concentrations of $\mathrm{CO}$ and $\mathrm{NO}_{2}$ were reduced by about $20 \%$ and $30 \%$, respectively [76]. \\
\hline City & 2021 & During lockdown periods, $\mathrm{PM}_{2.5}$ decreased by about $30 \%$ and $\mathrm{NO}_{2}$ by $50 \%$, respectively [77]. \\
\hline City & 2020 & The concentration of $\mathrm{PM}_{2.5}, \mathrm{PM}_{10}, \mathrm{NO}_{2}$, and $\mathrm{SO}_{2}$ decreased by about $6,14,25$, and $7 \%$, respectively [78]. \\
\hline City & 2021 & $\begin{array}{c}\text { The } \mathrm{PM}_{2.5} \text { and } \mathrm{SO}_{2} \text { were reduced from } 37 \text { to } 26 \mathrm{ug} / \mathrm{m}^{3} \text { and from } 6 \text { to } 4 \mathrm{ug} / \mathrm{m}^{3} \text {, respectively, during restricted } \\
\text { lockdown periods [79]. }\end{array}$ \\
\hline City & 2020 & $\begin{array}{l}\text { The concentration of } \mathrm{PM}_{2.5} \text { was higher during New Year holidays in } 2020 \text { (73\%) than New Year holidays in } 2019 \\
\text { (59\%) [80]. }\end{array}$ \\
\hline Country & 2020 & $\begin{array}{l}\text { In comparison to last year (2019), the concentrations of } \mathrm{CO}, \mathrm{NO}_{2}, \mathrm{SO}_{2}, \mathrm{PM}_{2.5} \text {, and } \mathrm{PM}_{10} \text { were reduced by about } 12 \text {, } \\
\qquad 16,12,15 \text {, and } 14 \% \text {, respectively [81]. }\end{array}$ \\
\hline Country & 2021 & Lockdown resulted in about a $50 \%$ reduction in $\mathrm{NO}_{2}[82]$ \\
\hline Country & 2021 & $\begin{array}{l}\text { The } \mathrm{NO}_{2} \text { was reduced by about } 53,50 \text {, and } 30 \% \text { in Wuhan, Hubei province, and China, respectively. The } \\
\text { concentration of } \mathrm{PM}_{2.5} \text { declined by about } 35,29 \text {, and } 19 \% \text {, respectively, in comparison to last year [83]. }\end{array}$ \\
\hline Country & 2020 & $\mathrm{NO}_{2}$ declined by about $24 \%$ during the Chinese New Year (CNY) holiday [84]. \\
\hline Country & 2020 & $\begin{array}{c}\text { The concentration of } \mathrm{NO}_{2} \text { was reduced by about } 20 \text { to } 50 \% \text { for cities, } 15 \text { to } 40 \% \text { for maritime transport, and } 40 \% \text { for } \\
\text { power plants [85]. }\end{array}$ \\
\hline
\end{tabular}
higher P resulted in a higher R in China. A $10 \mu \mathrm{g} / \mathrm{m}^{3}$ increase in P produced a $0.9 \%$ increase in R $(p<0.05)$. An interaction analysis between $\mathrm{P}$ and absolute humidity $(\mathrm{AH})$ showed a statistically significant positive relationship between $\mathrm{P} \times \mathrm{AH}$ and $\mathrm{R}(p<0.01)$. When $\mathrm{AH}$ was $\leq 8.6 \mathrm{~g} / \mathrm{m}^{3}$, higher $\mathrm{P}$ and AH produced a higher $\mathrm{R}(p<0.01)[74]$.

The number of days with $\mathrm{NO}_{2}, \mathrm{PM}_{10}$, and $\mathrm{PM}_{2.5}$ as the primary pollutants decreased by approximately 10,9 , and $15 \%$, respectively. We compared the wind direction, wind speed, temperature, and relative humidity from January-April 2020, 2019, 2018, and 2017, and found no obvious correlation between meteorological factors and

A causal relationship between $\mathrm{P}$ and $\mathrm{R}$ across 31 provincial capital cities in China was established via matching. A 
Table 3. Cont.

\begin{tabular}{|c|c|c|c|}
\hline Country & Study Area & Publication Year & Major Findings \\
\hline \multirow{7}{*}{ China } & Regional & 2020 & $\begin{array}{c}\text { There were reductions of } \mathrm{PM}_{2.5} \text { concentration from } 22.9 \% \text { to } 43 \% \text { during lockdown periods, as compared to } \\
\text { previous year [86]. }\end{array}$ \\
\hline & City & 2020 & A substantial reduction of $\mathrm{PM}_{2.5}, \mathrm{PM}_{10}, \mathrm{CO}$, and $\mathrm{SO}_{2}$ were reported during lockdown periods [87]. \\
\hline & Country & 2020 & Air pollution was reduced by up to $90 \%$ during city lockdown [88]. \\
\hline & Regional & 2020 & $\begin{array}{c}\text { The concentrations of } \mathrm{PM}_{2.5}, \mathrm{PM}_{10} \text {, and CO decreased by about } 40 \%, 45 \% \text {, and } 24 \% \text {, respectively, during lockdown } \\
\text { periods [89]. }\end{array}$ \\
\hline & Regional & 2020 & Carbonaceous particles decreased by about 20\% during lockdown periods [91]. \\
\hline & City & 2020 & $\begin{array}{l}\text { During lockdown periods, the concentration of } \mathrm{PM}_{2.5} \text { and } \mathrm{NO}_{2} \text { decreased by about } 36 \% \text { and } 53 \% \text {, respectively, and } \\
\qquad \mathrm{O}_{3} \text { increased by about } 116 \%[92] .\end{array}$ \\
\hline & Country & 2020 & During lockdown periods, the concentration of $\mathrm{PM}_{2.5}$ decreased by up to $23 \mathrm{ug} / \mathrm{m}^{3}$ [93]. \\
\hline \multirow{2}{*}{ Thailand } & City scale & 2020 & $\begin{array}{c}\text { Air quality improved by about } 50 \% \text { to } 70 \% \text { during lockdown periods due to restricted emissions from } \\
\text { transportation [94]. }\end{array}$ \\
\hline & City scale & 2020 & $\begin{array}{l}\text { The environmental benefits documented in major urban agglomerations during the lockdown may extend to } \\
\text { medium-sized urban areas as well [95]. }\end{array}$ \\
\hline \multirow{5}{*}{ Bangladesh } & City scale & 2021 & $\begin{array}{l}\text { Due to lockdown measures, significant differences between } \mathrm{PM}_{2.5}, \mathrm{SO}_{2}, \mathrm{NO}_{2}, \mathrm{CO} \text {, and } \mathrm{O}_{3} \text { in } 2019 \text { and } 2020 \text { were } \\
\text { observed in Dhaka city. We used lag-0, lag-7, lag-14, and lag-21 days on daily COVID-19 cases to look at the lag } \\
\text { effect of different air pollutants on meteorology [25]. }\end{array}$ \\
\hline & City scale & 2021 & $\begin{array}{c}\text { The concentration of } \mathrm{NO}_{2}, \mathrm{PM}_{2.5} \text {, and } \mathrm{SO}_{2} \text { decreased by about } 20 \%, 26 \% \text {, and } 17.5 \% \text {, respectively, because of } \\
\text { lockdown [38]. }\end{array}$ \\
\hline & City scale & 2021 & $\begin{array}{c}\text { The concentration of } \mathrm{PM}_{2.5} \text { and } \mathrm{PM}_{10} \text { decreased by } 40 \% \text { and } 32 \% \text { during lockdown periods in comparison to } \\
\text { previous dry seasons [96]. }\end{array}$ \\
\hline & Country scale & 2020 & The concentration of $\mathrm{NO}_{2}$ and $\mathrm{SO}_{2}$ decreased by about $40 \%$ and $43 \%$, respectively [97]. \\
\hline & City scale & 2020 & Air quality during lockdown was found to be $5.30 \%$ lower than 2019 [98]. \\
\hline \multirow[b]{2}{*}{ Malayasia } & Country and City scale & 2020 & $\mathrm{PM}_{.5}$ and $\mathrm{PM}_{10}$ decreased by about $25 \%$ during lockdown [99]. \\
\hline & City scale & 2020 & $\begin{array}{c}\text { Differences between } \mathrm{PM}_{10}, \mathrm{PM}_{2.5}, \mathrm{SO}_{2}, \mathrm{NO}_{2}, \mathrm{CO}, \mathrm{O}_{3} \text {, and solar radiation in } 2019 \text { and } 2020 \text { since the movement } \\
\text { control order (MCO) was implemented on } 18 \text { March } 2020 \text { [100]. }\end{array}$ \\
\hline Singapore & Country and City scale & 2020 & $\begin{array}{l}\text { The concentrations of the following pollutants } \mathrm{PM}_{10}, \mathrm{PM}_{2.5}, \mathrm{NO}_{2}, \mathrm{CO} \text {, and } \mathrm{SO}_{2} \text { decreased by } 23,29,54,6 \text {, and } 52 \% \\
\text { respectively, while that of } \mathrm{O}_{3} \text { increased by } 18 \% \text {. The Pollutant Standards Index decreased by } 19 \% \text { [101]. }\end{array}$ \\
\hline
\end{tabular}


Table 3. Cont

\begin{tabular}{|c|c|c|c|}
\hline \multirow{3}{*}{ Korea } & City scale & 2020 & $\begin{array}{c}\text { In March 2020, } \mathrm{PM}_{2.5} \text { showed remarkable reductions of } 36 \% \text { and } 30 \% \text { in Seoul and Daegu, respectively, when } \\
\text { compared with the same period from 2017-2019 [102]. }\end{array}$ \\
\hline & City scale & 2020 & $\begin{array}{c}\text { The } \mathrm{PM}_{2.5} \text { concentration decreased by about } 10.4 \% \text {, where the average concentration of } \mathrm{PM}_{2.5} \text { was } 23.7 \% \text { the last } \\
\text { 5 years [103]. }\end{array}$ \\
\hline & Country & 2021 & $\begin{array}{c}\text { The concentration of } \mathrm{PM}_{2.5}, \mathrm{PM}_{10} \text {, and } \mathrm{NO}_{2} \text { declined by about } 45,35 \text {, and } 20 \% \text {, respectively, because of } \\
\text { lockdown [104]. }\end{array}$ \\
\hline Israel & City scale & 2020 & $\begin{array}{l}\text { In its earlier closest period, the pollution from transport, based on nitrogen oxides, had reduced by } 40 \% \text { on average, } \\
\text { whereas the pollution from industry, based on Grand-level ozone had increased by } 34 \% \text { on average [105]. }\end{array}$ \\
\hline Iran & City scale & 2020 & $\begin{array}{c}\mathrm{PM}_{2.5} \text { increased by } 0.5-103,25 \text {, and } 2-50 \% \text {. In terms of the national air quality, } \mathrm{SO}_{2} \text { and } \mathrm{NO}_{2} \text { levels decreased, } \\
\text { while AOD } 26 \text { increased during the lockdown [106]. }\end{array}$ \\
\hline \multirow[b]{2}{*}{ Pakisthan } & Country & 2021 & $\begin{array}{c}\text { There were no significant improvements of air quality in Lahore and Karachi during lockdown periods, as } \\
\text { compared to } 2019 \text { [107]. }\end{array}$ \\
\hline & City scale & 2021 & $\begin{array}{l}\text { With the reduction in human activity (known to be the biggest source of air pollution) during the COVID-19 } \\
\text { pandemic, changes in air pollution values were observed. The year 2020, compared with } 2018 \text { and 2019, in order to } \\
\text { observe this change and to compare it with other years: } 1 \text { January-15 March, considered the pre-pandemic process; } \\
16 \text { March-31 May, considered the pandemic process; } 1 \text { June-30 June, considered the normalization process [108]. }\end{array}$ \\
\hline Vietnam & City scale & 2020 & The concentrations of $\mathrm{NO}_{2}, \mathrm{PM}_{2.5}$, and $\mathrm{SO}_{2}$ were reduced by about $75 \%, 55 \%$, and $67 \%$, respectively [110]. \\
\hline Kazakhstan & City scale & 2020 & $\mathrm{PM}_{2.5}$ declined by $21 \%$, and $\mathrm{CO}$ and $\mathrm{NO}_{2}$ decreased by about $49 \%$ and $35 \%$, respectively, during lockdown [111]. \\
\hline Saudi Arabia & Regional & 2021 & $\begin{array}{l}\text { The eastern province of Saudi Arabia reported a reduction in } \mathrm{PM}_{10}, \mathrm{CO} \text {, and } \mathrm{SO}_{2} \text { by } 21-70 \%, 5.8-55 \% \text {, and } 8.7-30 \% \text {, } \\
\text { respectively [112]. }\end{array}$ \\
\hline Teheran & Country & 2020 & $\begin{array}{l}\text { There were increases in } \mathrm{PM}_{2.5} \text { and } \mathrm{PM}_{10} \text { (by } 20.5 \% \text { and } 15.7 \% \text { ) during the first month of the COVID-19 outbreak } \\
\text { [113]. }\end{array}$ \\
\hline
\end{tabular}




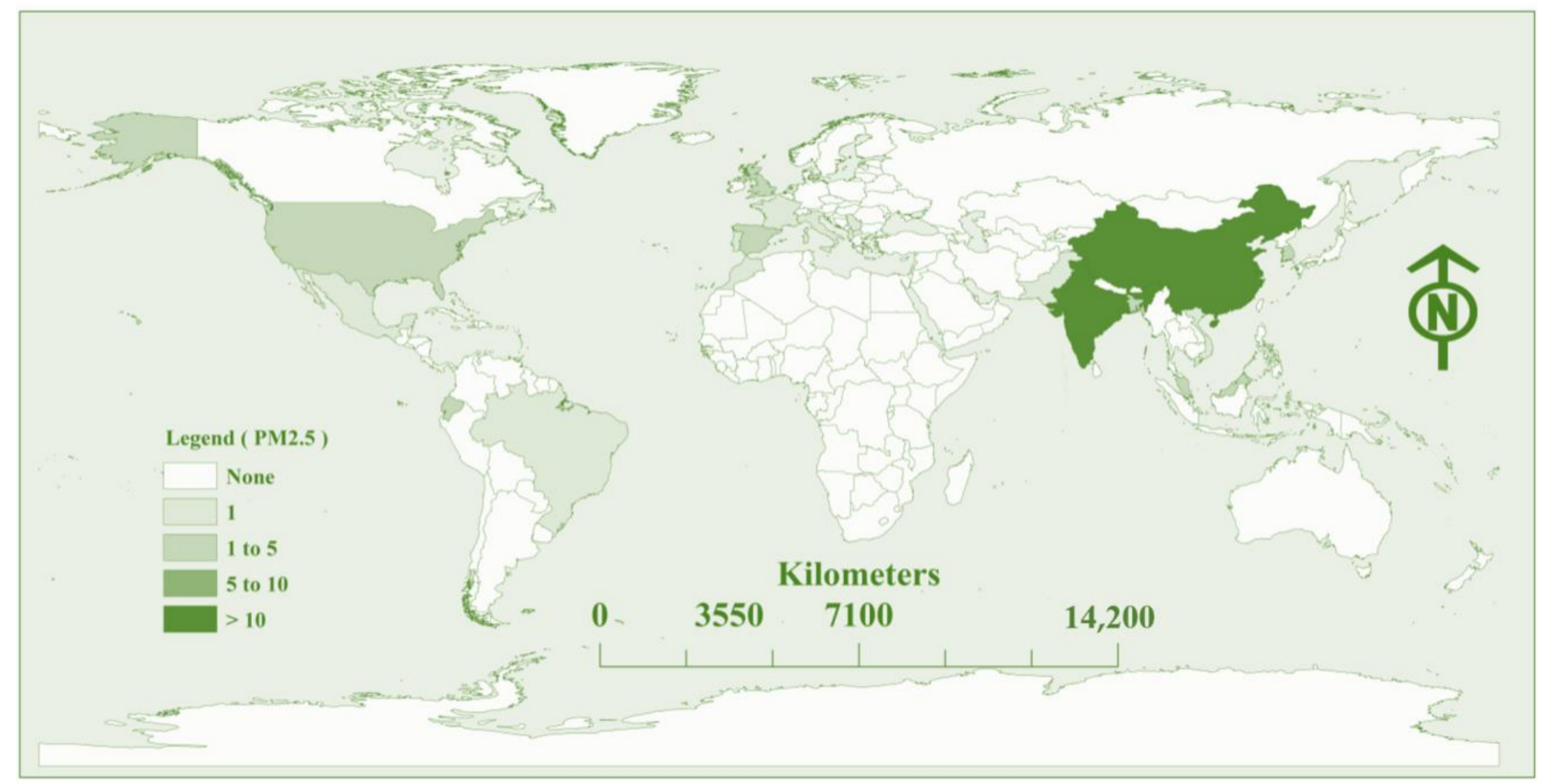

Figure 4. Studies focusing on $\mathrm{PM}_{2.5}$ concentrations.

\subsection{Impact of COVID-19 on Air Quality over European Countries}

After Asia, the second highest number of studies was performed on European countries. As per the literature survey, $33 \%$ of the total studies were collected from European countries. In this review, studies were collected from 13 countries in Europe with the highest number of studies on the UK (23\%), followed by Italy $(20 \%)$, Spain $(20 \%)$, Turkey $(8.8 \%)$, and France $(5.5 \%)$. The cities in Europe on which studies were performed were Barcelona, Madrid, Naples, the city of Novi Sad, Munich, Tirana, Southampton, and Milan. As per the literature survey, most of the studies were performed on the concentrations of $\mathrm{NO}_{2}$ (more than $50 \%$ of the study). As per the results of Anderson and Dirks [114] (2020), Lee et al. [115], and Jephcote et al. [116], the concentration of $\mathrm{NO}_{2}$ decreased by about $92 \%$, $42 \%$, and $38 \%$, respectively, in the UK Similarly, in Italy, the concentration of $\mathrm{NO}_{2}$ declined by about $49-62 \%$, and $\mathrm{SO}_{2}$ decreased by about $70 \%$ [117] during lockdown periods. Thus, from the previous studies, it is clear that there was a substantial decline in air pollutants, and air quality significantly improved during lockdown periods. The details of the impact of lockdown on air quality are presented in Table 4. Most of the studies focusing on the concentration of $\mathrm{PM}_{10}$ are presented in Figure 5. 
Table 4. Literature on the impact of COVID-19 on air quality in European countries.

\begin{tabular}{|c|c|c|c|}
\hline Country & Scale of Study & Publication Year & Major Findings \\
\hline \multirow{7}{*}{ UK } & England & 2021 & $\begin{array}{l}\mathrm{PM}_{2.5} \text { was a major contributor to COVID- } 19 \text { cases in England, as an increase of } 1 \mathrm{~m}^{3} \text { in the long-term average of } \\
\mathrm{PM}_{2.5} \text { was associated with a } 12 \% \text { increase in COVID-19 cases [118]. }\end{array}$ \\
\hline & Southampton & 2020 & $\mathrm{NO}_{2}$ decreased by about $92 \%$ during lockdown, as compared with the previous two years [114]. \\
\hline & Country & 2020 & $\mathrm{NO}_{2}$ was reduced by about $42 \%$ during lockdown periods [115]. \\
\hline & Country & 2021 & The concentration of $\mathrm{NO}_{2}$ and $\mathrm{PM}_{2.5}$ concentrations decreased by $38.3 \%$ and $16.5 \%$, respectively [116]. \\
\hline & Country & 2021 & The concentration of $\mathrm{NO}, \mathrm{NO}_{2}$, and $\mathrm{NO}_{x}$ decreased $32 \%$ to $50 \%$ at roadsides during lockdown [119]. \\
\hline & Country & 2021 & The concentration of $\mathrm{NO}_{2}$ decreased by about $50 \%$, and $\mathrm{O}_{3}$ increased by about $10 \%$ [121]. \\
\hline & Country & 2021 & The concentration of Ox emissions declined nationwide by $\sim 20 \%$ during the lockdown [122]. \\
\hline \multirow{5}{*}{ Spain } & City & 2020 & $\begin{array}{l}\text { The 4-week lockdown had a significant impact on reducing the atmospheric levels of } \mathrm{NO}_{2} \text { in all cities, except for } \\
\text { the small city of Santander, as well as the levels of } \mathrm{CO}, \mathrm{SO}_{2} \text {, and } \mathrm{PM}_{10} \text { in some cities, but resulted in an increase of } \\
\text { the } \mathrm{O}_{3} \text { level [123]. }\end{array}$ \\
\hline & Country & 2020 & $\begin{array}{l}\text { Changes in the concentration of the pollutant nitrogen dioxide }\left(\mathrm{NO}_{2}\right) \text { during the lockdown period were examined } \\
\text { as well as how these changes relate to the Spanish population [124]. }\end{array}$ \\
\hline & Country & 2021 & $\begin{array}{l}\text { Decreases in } \mathrm{PM}_{10} \text { levels were greater than in } \mathrm{PM}_{2.5} \text { because of reduced emissions from road dust, vehicle wear, } \\
\text { and construction/demolition activities. The averaged } \mathrm{O}_{3} \text { daily maximum of } 8 \text {-h }(8 \mathrm{hDM} \text { ) experienced a generalized } \\
\text { decrease in the rural receptor sites in the relaxation (June-July) with }-20 \% \text { reduced mobility [20]. }\end{array}$ \\
\hline & Country & 2020 & $\mathrm{NO}_{2}$ was reduced by about $50 \%$ during lockdown periods [126]. \\
\hline & City & 2020 & $\begin{array}{l}\text { The concentration of } \mathrm{NO}_{2} \text { in Barcelona and Madrid decreased by about } 50 \% \text { and } 62 \% \text {, respectively, during } \\
\text { lockdown periods [127]. }\end{array}$ \\
\hline \multirow{3}{*}{ Italy } & City & 2021 & $\begin{array}{l}\mathrm{NO}_{2} \text { decreased by about } 50 \%, 34 \% \text { and } 20 \% \text { from urban traffic, urban backgrounds, and rural backgrounds, } \\
\text { respectively [128]. }\end{array}$ \\
\hline & Regional & 2020 & $\begin{array}{l}\text { Potentially, it is the spatially confounding factors related to urbanization that may have influenced the spreading of } \\
\text { novel coronavirus. Our epidemiological analysis uses geographical information (e.g., municipalities) and Poisson } \\
\text { regression to assess whether both the ambient PM concentration and the excess mortality have a similar spatial } \\
\text { distribution [129]. }\end{array}$ \\
\hline & Regional & 2020 & $\begin{array}{l}\text { The estimate of the time series slope, i.e., the expected change in the concentration associated with a time unit } \\
\text { increase, decreased from }-0.25 \text { to }-1.67 \text { after the lockdown [130]. }\end{array}$ \\
\hline
\end{tabular}


Table 4. Cont.

\begin{tabular}{|c|c|c|c|}
\hline Country & Scale of Study & Publication Year & Major Findings \\
\hline \multirow{4}{*}{ Italy } & Country & 2021 & $\begin{array}{l}\text { The model finds that there is a positive nonlinear relationship between the density of particulate matter in the air } \\
\text { and COVID-19 transmission, which is in alignment with similar studies on other respiratory illnesses [131]. }\end{array}$ \\
\hline & City & 2021 & $\mathrm{NO}_{2}$ was reduced by about $49-62 \%$, and $\mathrm{CO}$ and $\mathrm{SO}_{2}$ declined by about $50-58 \%$ and $70 \%$, respectively [117]. \\
\hline & City & 2020 & There were significant reductions in $\mathrm{PM}_{2.5}, \mathrm{PM}_{10}, \mathrm{CO}$ and $\mathrm{NO}$, respectively [21]. \\
\hline & Regional & 2021 & The concentration of $\mathrm{PM}_{2.5}$ and $\mathrm{NO}_{2}$ declined by about $16 \%$ and $33 \%$, respectively [132]. \\
\hline \multirow{3}{*}{ Turkey } & Country & 2021 & $\begin{array}{l}\text { To determine the effects of COVID-19 measures on air quality in Turkey, for this investigation, the daily means of } \\
\mathrm{PM}_{10}, \mathrm{PM}_{2.5}, \mathrm{NO}_{2}, \mathrm{CO}, \mathrm{O}_{3} \text {, and } \mathrm{SO}_{2} \text { air pollutant data were used [133]. }\end{array}$ \\
\hline & Country & 2020 & By the end of April, the $\mathrm{PM}_{2.5}$ index had improved by about 35\% during lockdown [134]. \\
\hline & City & 2021 & The $\mathrm{NO}_{2}$ concentrations were reduced by about $11.8 \%$ in the after-virus period [135]. \\
\hline France & Country & 2020 & $\begin{array}{l}\text { Air quality in the Auvergne-Rhône-Alpes region, focusing on nine atmospheric pollutants }\left(\mathrm{NO}_{2}, \mathrm{NO}, \mathrm{PM}_{10}, \mathrm{PM}_{2.5}\right. \\
\mathrm{O}_{3}, \mathrm{VOC}, \mathrm{CO}, \mathrm{SO}_{2} \text {, and isoprene): In Lyon, the center of the region, the results indicated that } \mathrm{NO}_{2}, \mathrm{NO} \text {, and } \mathrm{CO} \\
\text { levels were reduced by } 67 \%, 78 \% \text {, and } 62 \% \text {, respectively, resulting from a decrease in road traffic by } 80 \% \text {. However } \\
\mathrm{O}_{3}, \mathrm{PM}_{10} \text {, and } \mathrm{PM}_{2.5} \text { were increased by } 105 \%, 23 \% \text {, and } 53 \% \text {, respectively [136]. }\end{array}$ \\
\hline Russia & City & 2020 & $\begin{array}{l}\text { Just under half were from changes in surface transport. At their peak, emissions in individual countries decreased } \\
\text { by }-26 \% \text { on average. The impact on } 2020 \text { annual emissions depends on the duration of the confinement, with a low } \\
\text { estimate of }-4 \%(-2 \text { to }-7 \%) \text { if pre-pandemic conditions return by mid-June, and a high estimate of }-7 \% \text { ( }-3 \text { to } \\
-13 \%)[137] \text {. }\end{array}$ \\
\hline Germany & City & 2021 & The concentration of $\mathrm{NO}_{2}$ reduced by about $15-25 \%$ and $34-36 \%$ from traffic sites during lockdown periods [138]. \\
\hline Macedonia & Country & 2020 & $\begin{array}{l}\mathrm{PM}_{2.5} \text { in Kumanovo and carbon monoxide in Skopje ( } 7 \% \text { and } 3 \% \text { higher concentrations, respectively). The most } \\
\text { notable decrement was for } \mathrm{NO}_{2} \text {, with a concentration 5-31\% lower during the COVID-19 period [139]. }\end{array}$ \\
\hline Portugal & Country & 2021 & $\mathrm{PM}_{10}$ and $\mathrm{NO}_{2}$ concentration was reduced by about $18 \%$ and $41 \%$, respectively [140]. \\
\hline Netherland & Country & 2021 & $\mathrm{NO}_{2}$ and $\mathrm{PM}_{10}$ concentration was reduced by about $18-30 \%$ and $20 \%$, respectively, during lockdown periods [141]. \\
\hline Poland & Country & 2021 & Aerosols concentrations were reduced by about $23 \%$ and $18 \%$ in April and May, respectively [76]. \\
\hline Serbia & City & 2021 & $\begin{array}{l}\text { The average daily concentrations of } \mathrm{PM}_{2.5}, \mathrm{NO}_{2}, \mathrm{PM}_{10} \text {, and } \mathrm{SO}_{2} \text { were reduced by } 35 \%, 34 \%, 23 \% \text {, and } 18 \% \text {, } \\
\text { respectively. In contrast, the average daily concentration of } \mathrm{O}_{3} \text { increased by } 8 \% \text {, even if the primary precursors } \\
\text { were reducing, thus representing a challenge for air quality management [142]. }\end{array}$ \\
\hline
\end{tabular}


Table 4. Cont.

Country

$$
\text { Scale of Study }
$$

\section{Publication Year}

2021

\section{Major Findings}

Viruses may persist in the air through complex interactions with particles and gases depending on: (1) chemical composition; (2) the electric charges of the particles; and (3) meteorological conditions, such as relative humidity, ultraviolet (UV) radiation, and temperature. In addition, by reducing UV radiation, air pollutants may promote viral persistence in the air and reduce vitamin D synthesis [143].

The lockdown effect on atmospheric composition, in particular through massive traffic reductions, has been important for several short-lived atmospheric trace species, with a large reduction in $\mathrm{NO}_{2}$ concentrations, a lower reduction in particulate matter $(\mathrm{PM})$ concentrations, and a mitigated effect on ozone concentrations due to nonlinear chemical effects [144]. 


\subsection{Impact of COVID-19 on Air Quality over North American Countries}

In North America, the greatest number of studies on air quality were performed on the United States and Canada. In this literature review, about $90 \%$ of the total studies were surveyed from the U.S., followed by Canada (10\%). Most of the studies in the U.S. were performed at the national level and the city scale (such as California and New Jersey). In the U.S., there were substantial reductions in air pollutants due to lockdown. For example, according to Goldberg et al. [146], $\mathrm{NO}_{2}$ declined by about $9 \%$ to $42 \%$, with the highest decline in San Jose and Los Angeles, and the lowest decrease (<12\%) in Miami, Minneapolis, and Dallas. As per the study of Jiang et al. (2020), $\mathrm{PM}_{2.5}$ concentration was reduced by more than $68 \%$ after lockdown. Moreover, other studies in the U.S. also revealed that there was a significant decrease in the air pollutant concentrations during lockdown periods that resulted in a substantial improvement in air quality (Table 5). The studies focusing on the assessment of $\mathrm{CO}$ are shown in Figure 6.

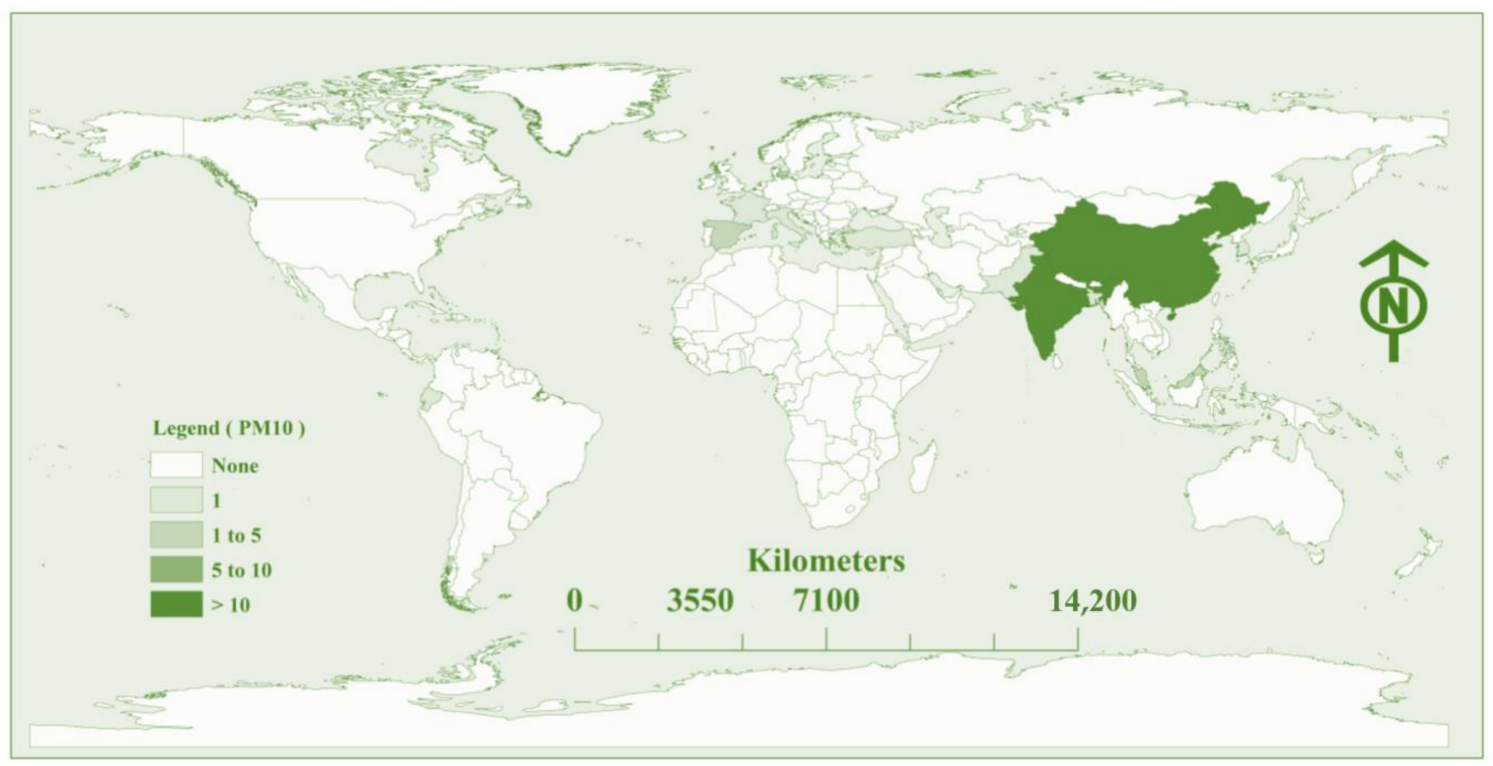

Figure 5. Studies focusing on $\mathrm{PM}_{10}$ concentrations.

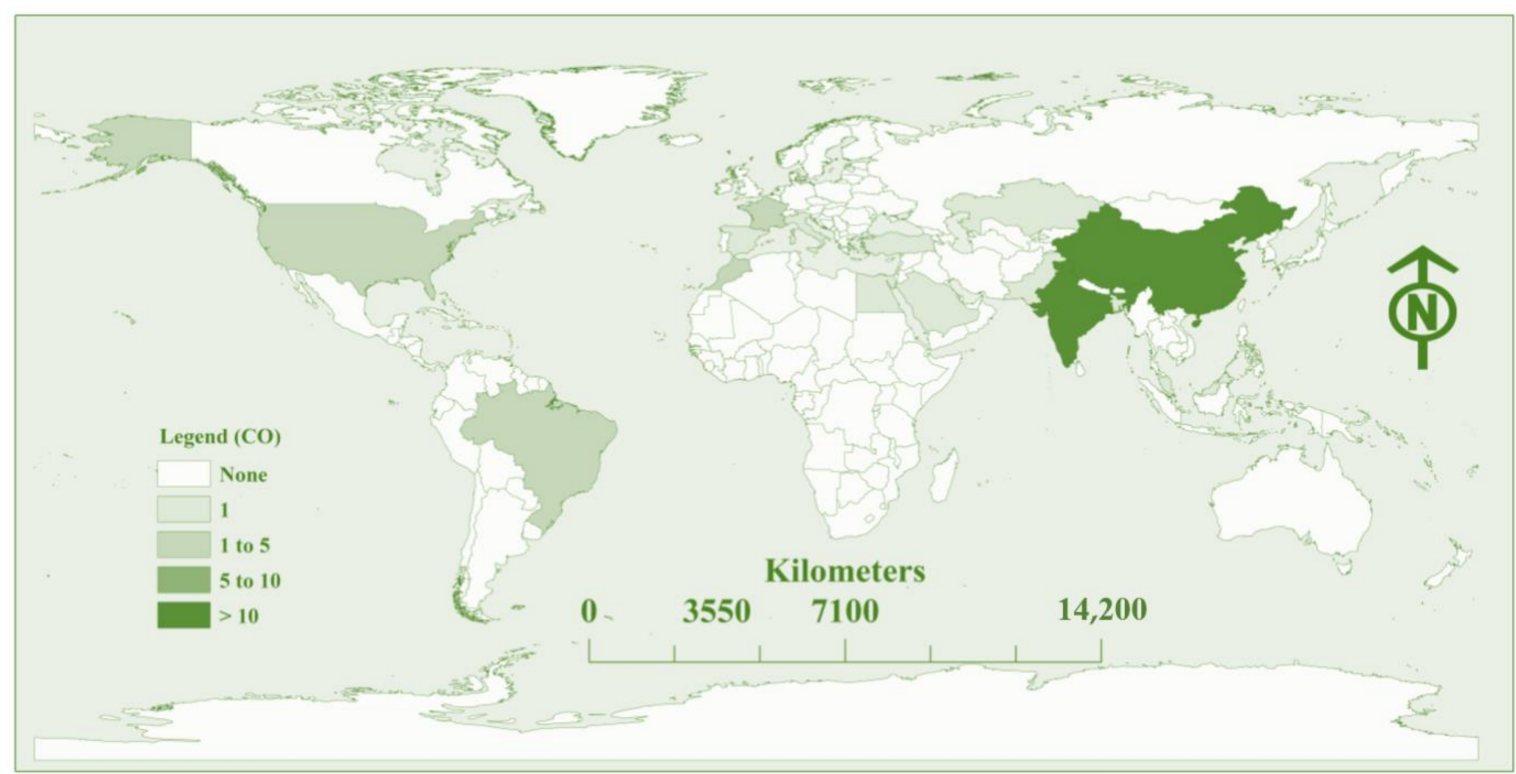

Figure 6. Studies focusing on CO concentrations. 
Table 5. Literature on the impact of COVID-19 on air quality in North American countries.

Country Scale of the Study Publication Year

City

City

Country

Country

US

US

City

City
2020

2020

2020

2020

2020

2021

2020

\section{Major Findings}

The surface air quality monitoring data from the United States Environmental Protection Agency's (U.S. EPA)

AirNow network, during the period from 20 March-5 May in 2020, to the 2015-2019 period, from the Air Quality System (AQS) network over the state of California. The results indicate changes in fine particulate matter $\left(\mathrm{PM}_{2.5}\right)$ of $-2.04 \pm 1.57 \mu \mathrm{g} \mathrm{m}^{-3}$ and ozone of $-3.07 \pm 2.86 \mathrm{ppb}$. If the air quality improvements persist over a year, it could potentially lead to 3970-8900 preventable premature deaths annually (note: the estimates of preventable premature deaths have large uncertainties). Public transit demand showed dramatic declines ( $80 \%)$ [147].

COVID-19 prevalence and fatality (plotted as logarithm-transformed prevalence/fatality on the $y$-axis) as a

function of mean ozone $/ \mathrm{PM}_{2.5} \mathrm{AQI}$ (plotted on the $x$-axis). Coefficients were not statistically significant for ozone $\left(p=0.212 / 0.814\right.$ for prevalence/fatality) and $\mathrm{PM}_{2.5}(p=0.986 / 0.499)$ [148].

The concentration of $\mathrm{NO}_{2}$ was reduced by about $25 \%$ in comparison to past years [149].

The $\mathrm{NO}_{2}$ concentration was reduced by about 5 to $49 \%$, with a mixed impact on $\mathrm{O}_{3}( \pm 20 \%)$ [24].

$\mathrm{NO}_{2}$ decreased by about $9-42 \%$, with the highest decreases $(>30 \%)$ in San Jose and Los Angeles, and the lowest decreases $(<12 \%)$ in Miami, Minneapolis, and Dallas [146].

$\mathrm{PM}_{2.5}$ concentration was reduced by about $68 \%$ after lockdown [150].

There were decreases of $\mathrm{PM}_{2.5}$ and $\mathrm{NO}_{2}$ by $36 \%$ and $51 \%$, respectively, during lockdown [151].

As per ground-based observation, it was reported that the concentration of $\mathrm{NO}_{2}, \mathrm{CO}$, and $\mathrm{PM}_{2.5}$ dropped by about $38 \%, 49 \%$, and 31\%, respectively, during lockdown periods (19 March to 7 May 2020) [152].

Canada City 


\subsection{Impact of COVID-19 on Air Quality over South American Countries}

In South America, the greatest number of studies were performed on Brazil, Ecuador, and Mexico. In this review, about $40 \%$ of the total studies were surveyed from Brazil and Ecuador, followed by Mexico (20\%). As per the results of the study, it was documented that there was a substantial improvement in air quality during lockdown periods. According to Hernández-Paniagua et al. [154], the concentration of $\mathrm{NO}_{2}$ was reduced by between $10 \%$ and 35\% in Mexico during lockdown periods. Zalakeviciute et al. [155] performed a study in Quito (Ecuador), and the findings of the study show that air quality improved by about $26 \%$ to $68 \%$. According to Nakada and Urban [156], NO, $\mathrm{NO}_{2}$, and $\mathrm{CO}$ decreased by about $70 \%, 50 \%$, and $60 \%$, respectively, in Sau Paulo (Brazil). The details of the findings on the impact of lockdown on air quality are presented in Table 6 . The studies focusing on the assessment of $\mathrm{NO}_{2}$ are shown in Figure 7.

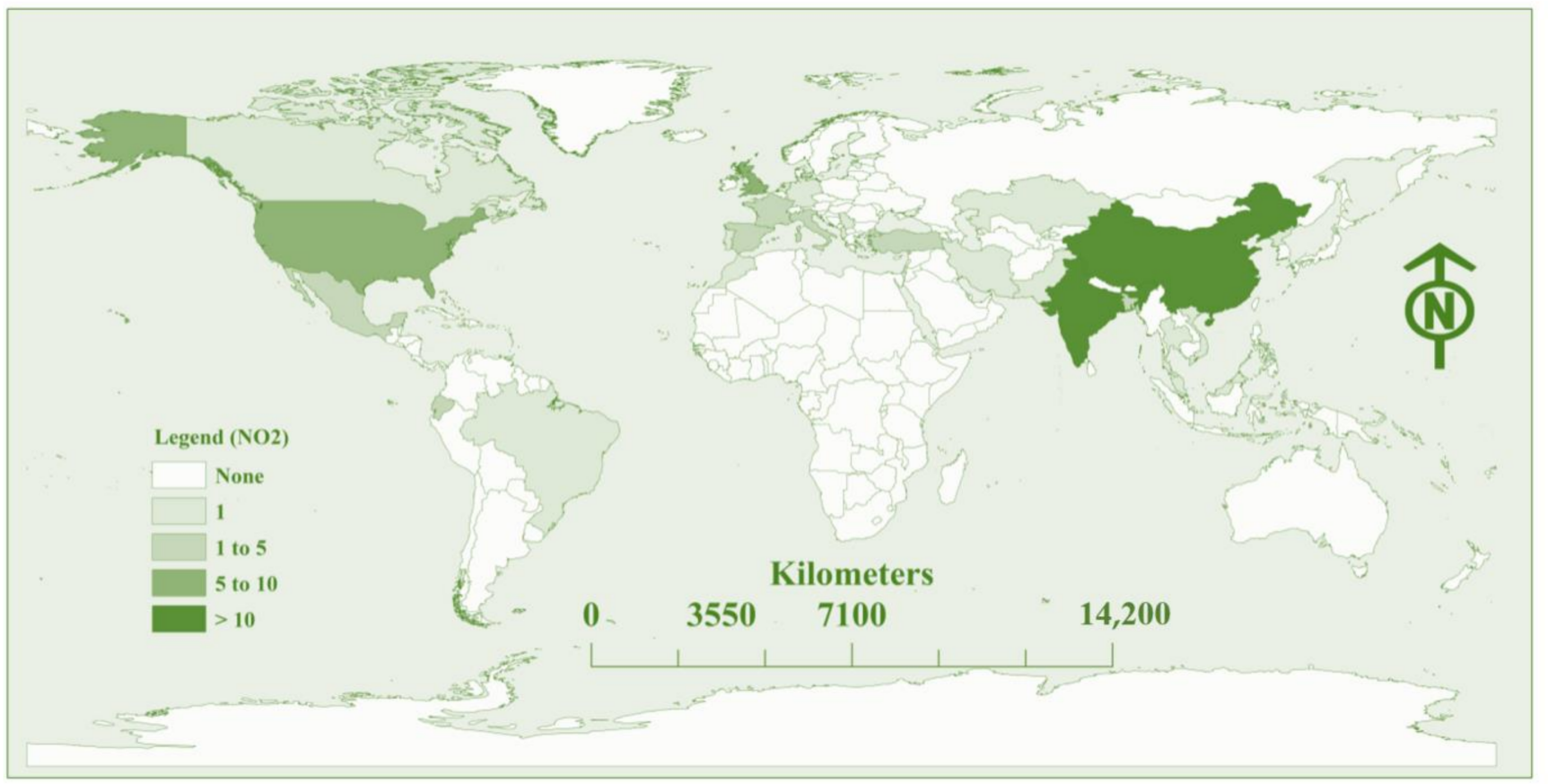

Figure 7. Studies focusing on $\mathrm{NO}_{2}$ concentrations.

Table 6. Literature on the impact of COVID-19 on air quality in South American countries.

\begin{tabular}{|c|c|c|c|}
\hline Country & Scale of the Study & Publication Year & Major Findings \\
\hline \multirow[t]{3}{*}{ Brazil } & City & 2020 & $\begin{array}{l}\text { There was a substantial decrease of } \mathrm{NO} \text { (more than } 70 \% \text { ), } \mathrm{CO} \\
\text { (more than } 60 \% \text { ), and } \mathrm{NO}_{2} \text { (more than } 50 \% \text { ). Ozone concentration } \\
\text { increased by about } 30 \% \text { during partial lockdown periods, as } \\
\text { compared to previous years [11]. }\end{array}$ \\
\hline & City Scale & 2020 & $\begin{array}{l}\text { Among } \mathrm{CO}, \mathrm{NO}_{2} \text {, and } \mathrm{PM}_{2.5} \text {, a significant reduction was reported } \\
\text { for } \mathrm{CO}(30-48 \%) \text { [157]. }\end{array}$ \\
\hline & City Scale & 2020 & $\begin{array}{l}\text { During lockdown, CO reported the highest decline of up to } 100 \% \text {. } \\
\mathrm{NO}_{2} \text { decreased by about } 9 \text { to } 41 \% \text { [158]. }\end{array}$ \\
\hline \multirow{3}{*}{ Ecuador } & City & 2020 & $\begin{array}{l}\text { The concentration of } \mathrm{NO}_{2} \text { and } \mathrm{PM}_{2.5} \text { significantly decreased due } \\
\text { to the implementation of lockdown. The concentration of } \mathrm{PM}_{2.5} \\
\text { was lower in 2020, as compared to } 2018 \text { and } 2019 \text { during the same } \\
\text { lockdown periods i.e. March [159]. }\end{array}$ \\
\hline & City & 2021 & $\begin{array}{l}\text { There was a substantial reduction in NO during lockdown } \\
\text { periods [160]. }\end{array}$ \\
\hline & Regional & 2020 & $\begin{array}{l}\text { The concentration of } \mathrm{PM}_{2.5}, \mathrm{PM}_{10} \text {, and } \mathrm{NO}_{2} \text { decreased by about } \\
40 \%, 44 \% \text { and } 60 \% \text {, respectively, during strict lockdown, and } 69 \% \text {, } \\
58 \% \text {, and } 62 \% \text {, respectively, during relaxed lockdown } \\
\text { periods }[155] \text {. }\end{array}$ \\
\hline
\end{tabular}


Table 6. Cont.

\begin{tabular}{cccl}
\hline Country & Scale of the Study & Publication Year & \multicolumn{1}{c}{ Major Findings } \\
\hline Ecuador & Country & 2020 & Air quality improved by 29-68\% due to lockdown [161]. \\
Mexico & Country & 2020 & $\begin{array}{l}\text { The concentrations of } \mathrm{NO}_{2}, \mathrm{SO}_{2}, \text { and } \mathrm{PM}_{10} \text { declined by about 29, } \\
\end{array}$
\end{tabular}

\subsection{Impact of COVID-19 on Air Quality over African Countries}

In this review, four countries were surveyed from Africa, with the highest percentage of studies on Morocco (42\%), followed by Egypt (28\%), Uganda $(14.3 \%)$, and Nigeria (14.3\%) (Table 7). In African countries, there were also significant improvements in air quality during lockdown periods. For example, as per the study by Otmani et al. [162], the concentration of $\mathrm{PM}_{2.5}$ and $\mathrm{PM}_{10}$ decreased by about $75 \%$ and $96 \%$, respectively, during lockdown periods. Similarly, $\mathrm{CO}$ and $\mathrm{NO}_{2}$ decreased by about $46 \%$ and $45 \%$, respectively. The studies focusing on the assessment of $\mathrm{SO}_{2}$ are shown in Figure 8.

Table 7. Literature on the impact of COVID-19 on air quality in African countries.

\begin{tabular}{|c|c|c|c|}
\hline Country & Scale of the Study & Publication Year & Major Findings \\
\hline \multirow[t]{2}{*}{ Egypt } & Country & 2020 & $\begin{array}{l}\text { The whole country is improved as a result of reduced pollutant } \\
\text { emissions, with } \mathrm{NO}_{2} \text { reduced by } 45.5 \% \text {, CO emissions reduced by } \\
46.23 \% \text {, ozone concentration decreased by about } 61.1 \% \text {, and AOD } \\
\text { reduced by } 68.5 \% \text {, compared to the previous two years [163]. }\end{array}$ \\
\hline & City & 2021 & $\begin{array}{c}\text { Absorbing aerosol index (AAI) and } \mathrm{NO}_{2} \text { decreased by about } 30 \% \\
\text { and } 15 \% \text {, respectively, and } 33 \% \text { in Cairo and Alexandria } \\
\text { Governorate [22]. }\end{array}$ \\
\hline Morocco & City Scale & 2020 & $\begin{array}{c}\mathrm{PM}_{10} \text { and } \mathrm{NO}_{2} \text { decreased by about } 75 \% \text { and } 96 \% \text {, } \\
\text { respectively [164]. }\end{array}$ \\
\hline Morocco & Country & 2020 & $\begin{array}{l}\text { COVID-19-compelled lockdown may have saved lives by } \\
\text { restraining air pollution, thereby preventing infection. We found } \\
\text { that } \mathrm{NO}_{2} \text { dropped by }-12 \mu \mathrm{g} / \mathrm{m}^{3} \text { in Casablanca, and by }-7 \mu \mathrm{g} / \mathrm{m}^{3} \\
\text { in } \mathrm{Marrakech}^{3} \mathrm{PM}_{2.5} \text { dropped by }-18 \mu \mathrm{g} / \mathrm{m}^{3} \text { in Casablanca, and } \\
-14 \mu \mathrm{g} / \mathrm{m}^{3} \text { in Marrakech. CO dropped by }-0.04 \mathrm{mg} / \mathrm{m}^{3} \text { in } \\
\text { Casablanca, and }-0.12 \mathrm{mg} / \mathrm{m}^{3} \text { in Marrakech [165]. }\end{array}$ \\
\hline Uganda & City Scale & 2020 & $\begin{array}{l}\text { (i) The COVID-19-induced lockdown period. The data has been } \\
\text { compared with the same period of the previous year. Promising } \\
\text { and notable observations were made in terms of the AQI of } \\
\text { Kampala [166]. }\end{array}$ \\
\hline Nigeria & City Scale & 2021 & $\begin{array}{l}\text { The lockdown resulted in a decrease of } \mathrm{SO}_{2} \text { and } \mathrm{NO}_{2} \text { across the } \\
\text { cities. For example, } 1.1 \% \text { and } 215.5 \% \text { of } \mathrm{NO}_{2} \text { and } \mathrm{SO}_{2} \text {, respectively, } \\
\text { from the city Port Harcourt [167]. }\end{array}$ \\
\hline
\end{tabular}

\subsection{Number of Publications and Journal Distributions}

As per literature screening from different sources, it was observed that there were more than 300 studies performed on the impact of lockdown on air quality across the world (as per our observations from April 2020 to March 2021). Among all the countries, the greatest number of studies were performed on Asian countries, followed by European countries. From the literature screening, it was well-recognized that the greatest number of research studies were published by Science of The Total Environment (about 29\%), followed by Aerosol and Air Quality Research (23\%), Air Quality, Atmosphere \& Health (9\%), Environmental Pollution (6\%), and Environmental Research (4\%). From the top ten journals, about $80 \%$ of the total studies were included (Figures 9 and 10). 


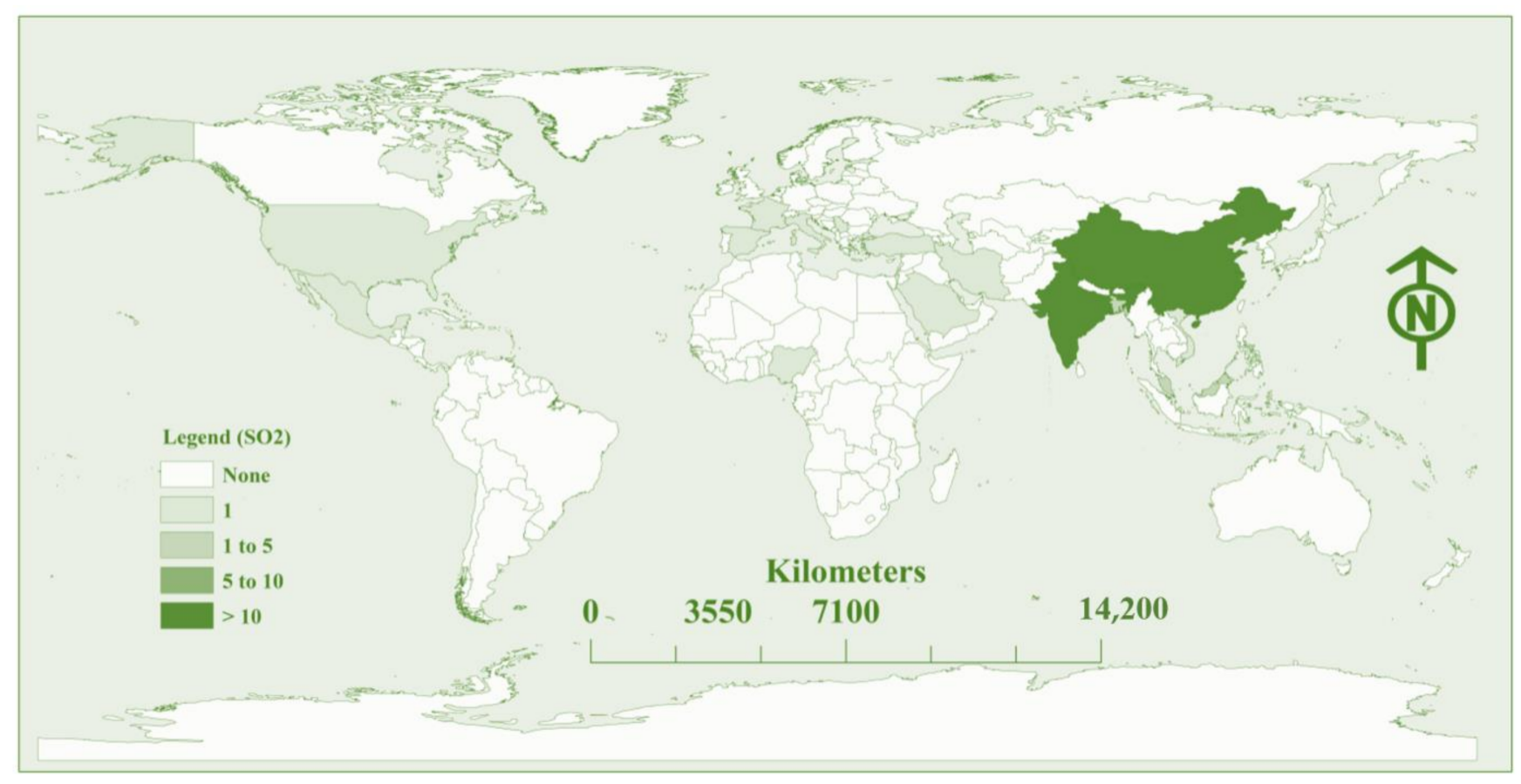

Figure 8. Studies focusing on $\mathrm{SO}_{2}$ concentration.

The Egyptian Journal of Remote Sensing and Space Sciences Geophysical Research Letters

International Journal of Environmental Health Research

Chemosphere

Remote Sensing Applications: Society and Environment

Environmental Science \& Technology

Atmospheric Pollution Research

Remote Sensing

Atmosphere

Journal of Environmental Sciences

International Journal of Environmental Research and Public Health

Atmospheric Chemistry and Physics

Environmental Research Letters

Atmospheric Environment

Environmental Science and Pollution Research

Urban Climate

Environmental Research

Environmental Pollution

Air Quality, Atmosphere, and Health

Aerosol and Air Quality Research

Science of the Total Environment

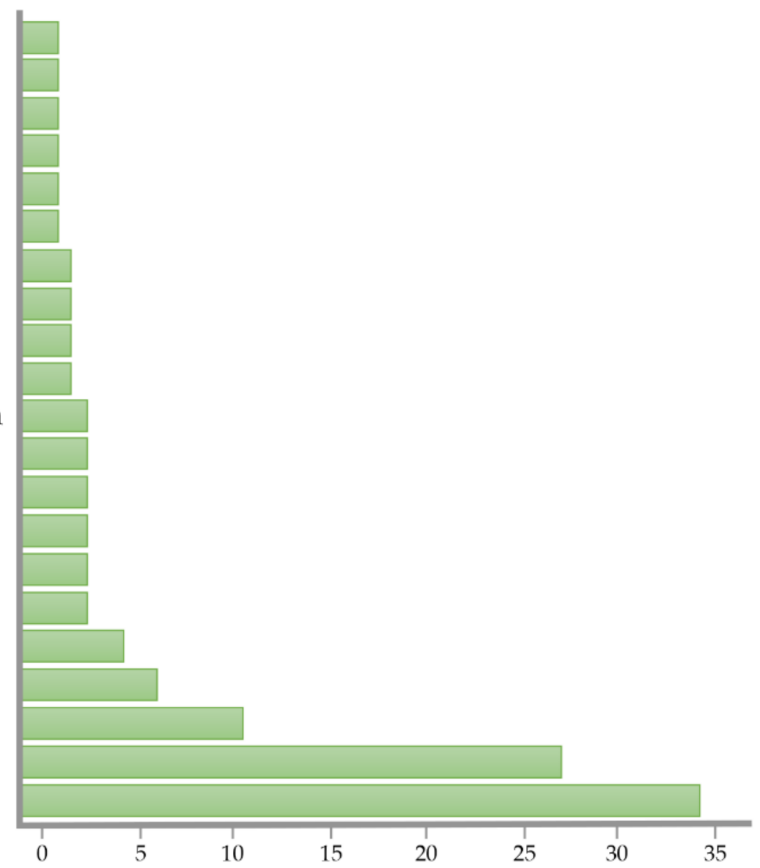

Figure 9. Contribution of major journals as per the literature screening (\%). 
Atmospheric Chemistry and Physics

Environmental Research Letters

Atmospheric Environment

Environmental Science and Pollution Research

Urban Climate

Environmental Research

Environmental Pollution

Air Quality, Atmosphere, and Health

Aerosol and Air Quality Research

Science of the Total Environment

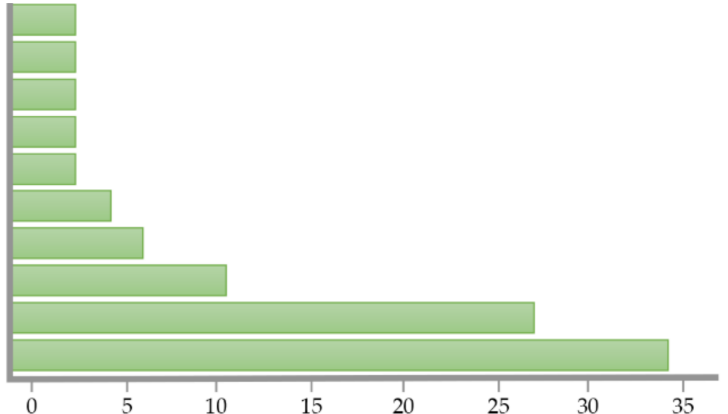

Figure 10. Top 10 journals as per the literature screening (\%).

\section{Discussion}

The present study mainly focuses on a review on the impact of COVID-19 lockdowns on air quality around the globe. From the results, it was found that most of the studies on the impact of lockdowns on air quality were performed in Asian countries (about 65\%), followed by European countries (18\%), and North and South American countries (10\%). As per the literature screening, it was reported that the greatest number of studies on the impact of lockdown on air quality were reported from India (29\%), followed by China (23\%), the UK $(4.44 \%)$, and Italy (3.89\%). From the previous research studies, it was recognized that there was a strong association between air pollutants and respiratory disease [168-170]. Thus, the areas with high exposure to air pollution are vulnerable to mortalities due to respiratory diseases. With COVID-19 being a respiratory disease, it is obvious that COVID19 deaths are strongly influenced by air pollutants. Recent studies also show that the concentrations of air pollutants are significant risk factors in COVID-19 deaths [171-174]. In many studies across the cities of the world, it is reported that concentrations of air pollutants are strongly associated with COVID-19 cases, as well as deaths. The severely affected countries of the world imposed several measures to fight COVID-19 and reduce the transmission of the virus around the world [47]. China was the first country to implement a complete shutdown in commercial fields, restrictions on domestic and international travel, and strict COVID-19 protocols were imposed across affected cities [175]. After that, similar restrictions were implemented by several other countries, such as India, Italy, and France. These restrictions were placed on public transportation, social gatherings, schools and colleges, and emissions from industries as well (Das et al., 2020). Economic activities are the prime factors that contribute to environmental pollution because of the combustion of fuel and the release of air pollutants into the atmosphere [175]. In most of the densely populated cities, particularly the ones in developing countries, air pollution levels are higher than the tolerance limits, and that results in risks to human health. In urban areas, the concentration of primary air pollutants, such as $\mathrm{CO}, \mathrm{NO}_{2}, \mathrm{SO}_{2}, \mathrm{O}_{3}$ are significantly higher. The concentrations of particulate matters $\left(\mathrm{PM}_{2.5}\right.$ and $\left.\mathrm{PM}_{10}\right)$ were significantly decreased during lockdown periods due to the restriction on emissions from various sources [18]. A substantial improvement in air quality was reported for most polluted cities around the world, such as Delhi (the capital city of India, India), Dhaka (the capital city of Bangladesh), and Beijing (China). Thus, COVID-19 lockdowns have had positive impacts on the environment. Therefore, from the overall results, it can be stated that lockdown, particularly short-term lockdown, can, to some extent, be considered an alternative measure to reduce air pollution level. The outbreak of COVID-19 compelled the affected countries to impose lockdowns to curb COVID-19 transmission, and many countries have remained under partial lockdown since last year. Thus, the environment has had a long time to restore its capacity because of the cessation of many economic activities. However, in reality, it is not possible to completely cease economic activity because it is a matter of human livelihoods. So, planners and policymakers must implement and follow sustainable strategies to reduce air pollution levels. The lockdowns during COVID-19 not only induced the improvement of air quality, but it has also had other positive effects on 
the environment. Measures regarding social distancing kept people away from resorts and sea beaches, and effluent discharge into the water stopped because of industrial shutdowns. Water quality also improved in many countries, such as in Spain, Equador, and Mexico. For instance, as per the findings of Paital et al. (2020), and Saadat et al. (2020), the water quality of Venice's canals, and the Yamuna River in Delhi, improved significantly in comparison with past years. Apart from environmental perfectives, COVID-19 lockdowns also had a substantial impact on the global economy. As per a World Trade Organization (WTO, 2020) report, economic activity decreased in world trade between $13 \%$ and $32 \%$. Thus, it has been well-documented in previous literature that COVID-19 lockdowns result in substantial positive, as well as negative, impacts on the environment.

The present review study on the impact of COVID-19 lockdowns on air quality across the globe can provide a unique work for understanding, as well as implementing, effective strategies at the city, regional, and country scales. For example, among all the regions, Asian countries, such as India, China, and Bangladesh, are more severely affected by extreme air pollution levels. At the country scale, most of the studies were performed in India, followed by China, and the UK Thus, at the global scale, effective strategies can be implemented for the Asian region to fight air pollution levels, and at the country scale (such as with India), cities can be identified through this literature and strategies for them can thus be implemented. Therefore, this study may be very helpful to planners and policymakers for understanding the global scenario and the improvement of air quality due to COVID-19 lockdowns. In this study, few limitations can be identified. Firstly, in this study, the literature was reviewed from March 2020 to April 2021. No studies were taken into consideration that were published after April 2021 in this review assessment. Thus, further research in the future can be performed on literature published after April 2021 for a better understanding of the impact of lockdown on air quality. Secondly, no models or laws were applied in this study for literature screening. Thus, for future researchers, we suggest implementing the Bradford law for literature screening. In spite of these limitations of the study, this is a unique piece of research into the global scenario with respect to the impact of COVID-19 lockdowns on air quality.

\section{Conclusions}

In this study, an attempt has been made to examine and review the impact of COVID19 lockdowns on air quality on a global scale. Initially, 237 studies related to the impact of COVID-19 lockdowns on air quality were screened, and 144 studies were finally taken into account for this literature review. The literature was extracted from Scopus, Google Scholar, PubMed, Web of Science, and the Google search engine. The Preferred Reporting Items for Systematic Reviews and Meta-Analyses (PRISMA) was also used for the literature screening. As per the results of this study, it is well-documented that most of the studies were performed over the Asian region (65\%), followed by Europe (18\%), North America $(6 \%)$, South America (5\%), and Africa (3\%). At the country scale, the greatest number of studies were conducted in India (29\%), followed by China (23\%), the U.S. (5\%), the UK $(4 \%)$, and Italy. As per our investigation, it was observed that the greatest number of studies on the impact of the COVID-19 pandemic on air quality was published in Science of the Total Environment (29\%), followed by Aerosol and Air Quality Research (23\%), Air Quality, Atmosphere E Health (9\%), and Environmental Pollution (5\%). From the core findings of the literature, it is apparent that there was substantial improvement in air quality due to lockdowns across the world. For example, Naqvi et al. [19] performed a study on India and reported that the air quality index was reduced by about $40 \%$ during one month of lockdown. According to Filonchyk et al. [76], and Diamond and Wood [82], the concentrations of $\mathrm{CO}$ and $\mathrm{NO}_{2}$ were reduced by about $20 \%$ and $30 \%$, respectively, and by $50 \%$ in China. In the UK, $\mathrm{NO}_{2}$ was reduced by about $42 \%$ during lockdown periods [107]. Thus, in all of the countries, it has been well-recognized that there was a substantial improvement in air quality during the lockdowns. The implementation of lockdowns around the world resulted in the improvement of the air quality and provided us with an 
opportunity to realize the impact of the anthropogenic pressures on the environment. Thus, the findings of the review will surely assist planners and policymakers to understand that the implementation of lockdowns may be an effective measure to restore the environment, and to build quality ecosystems in urban environments. All the affected countries of the world imposed effective measures to try to slow down the transmission of COVID-19. These measures included the closures of industrial activities, strict restrictions on transportation, and the cessation of other productive activities that resulted in the improvement of air quality.

Author Contributions: Methodology, A.A. and A.M.; software, A.A. and A.M.; formal analysis, A.A. and A.M.; resources, A.A. and A.M.; data curation, A.A. and A.M.; writing-original draft preparation, A.A.; writing-review and editing, A.A. and A.M.; visualization, A.A. and A.M.; supervision, A.A.; funding acquisition, A.A. All authors have read and agreed to the published version of the manuscript.

Funding: This research received no external funding.

Institutional Review Board Statement: Not applicable.

Informed Consent Statement: Informed consent was obtained from all subjects involved in the study.

Data Availability Statement: The data presented in this study are available on request from the corresponding author. The data are not publicly available due to privacy reasons.

Conflicts of Interest: The authors declare no conflict of interest.

\section{References}

1. World Health Organization. World Health Statistics 2016: Monitoring Health for the SDGs Sustainable Development Goals; World Health Organization: Geneva, Switzerland, 2016.

2. Anenberg, S.; Horowitz, L.; Tong, D.; West, J.J. An Estimate of the Global Burden of Anthropogenic Ozone and Fine Particulate Matter on Premature Human Mortality Using Atmospheric Modeling. Environ. Health Perspect. 2010, 118, 1189-1195. [CrossRef] [PubMed]

3. Krewski, D.; Jerrett, M.; Burnett, R.T.; Ma, R.; Hughes, E.; Shi, Y.; Turner, M.; Pope, C.; Thurston, G.; Calle, E.; et al. Extended Follow-Up and Spatial Analysis of the American Cancer Society Study Linking Particulate Air Pollution and Mortality; Health Effects Institute: Boston, MA, USA, 2009; pp. 5-114.

4. Slama, R.; Darrow, L.; Parker, J.; Woodruff, T.J.; Strickland, M.; Nieuwenhuijsen, M.; Glinianaia, S.; Hoggatt, K.; Kannan, S.; Hurley, F.; et al. Meeting Report: Atmospheric Pollution and Human Reproduction. Environ. Health Perspect. 2008, 116, 791-798. [CrossRef]

5. Smith, K.R.; Bruce, N.; Balakrishnan, K.; Adair-Rohani, H.; Balmes, J.; Chafe, Z.; Dherani, M.; Hosgood, H.; Mehta, S.; Pope, D.; et al. Millions dead: How do we know and what does it mean? Methods used in the comparative risk assessment of household air pollution. Annu. Rev. Public Health 2014, 35, 185-206. [CrossRef]

6. Pedersen, M.; Giorgis-Allemand, L.; Bernard, C.; Aguilera, I.; Andersen AM, N.; Ballester, F.; Beelen, R.; Chatzi, L.; Cirach, M.; Danileviciute, A.; et al. Ambient air pollution and low birthweight: A European cohort study (ESCAPE). Lancet Respir. Med. 2013, 1, 695-704. [CrossRef]

7. Pope, C.A.; Rodermund, D.L.; Gee, M.M. Mortality Effects of a Copper Smelter Strike and Reduced Ambient Sulfate Particulate Matter Air Pollution. Environ. Health Perspect. 2007, 115, 679-683. [CrossRef] [PubMed]

8. Sun, Z.; Yang, L.; Bai, X.; Du, W.; Shen, G.; Fei, J.; Wang, Y.; Chen, A.; Chen, Y.; Zhao, M. Maternal ambient air pollution exposure with spatial-temporal variations and preterm birth risk assessment during 2013-2017 in Zhejiang Province, China. Environ. Int. 2019, 133, 105242. [CrossRef] [PubMed]

9. Weinmayr, G.; Hennig, F.; Fuks, K.; Nonnemacher, M.; Jakobs, H.; Möhlenkamp, S.; Erbel, R.; Jöckel, K.; Hoffmann, B.; Moebus, S.; et al. Long-term exposure to fine particulate matter and incidence of type 2 diabetes mellitus in a cohort study: Effects of total and traffic-specific air pollution. Environ. Health 2015, 14, 1-8. [CrossRef]

10. GBD. The Global Burden of Disease, 2018, GBD. In The Global Burden of Disease. Generating Evidence and Guiding Policy; Institute for Health Metrics and Evaluation: Seattle, WA, USA, 2018.

11. Dantas, G.; Siciliano, B.; França, B.B.; da Silva, C.M.; Arbilla, G. The impact of COVID-19 partial lockdown on the air quality of the city of Rio de Janeiro, Brazil. Sci. Total Environ. 2020, 729, 139085. [CrossRef]

12. Ibe, F.C.; Opara, A.I.; Duru, C.E.; Obinna, I.B.; Enedoh, M.C. Statistical analysis of atmospheric pollutant concentrations in parts of Imo State, Southeastern Nigeria. Sci. Afr. 2020, 7, e00237. [CrossRef]

13. Otmani, A.; Benchrif, A.; Tahri, M.; Bounakhla, M.; Chakir, E.M.; El Bouch, M.; Krombi, M. Impact of Covid-19 lockdown on $\mathrm{PM}_{10}, \mathrm{SO}_{2}$ and $\mathrm{NO}_{2}$ concentrations in Salé City (Morocco). Sci. Total Environ. 2020, 735, 139541. [CrossRef] [PubMed] 
14. Tobías, A.; Carnerero, C.; Reche, C.; Massagué, J.; Via, M.; Minguillón, M.C.; Via, M.; Minguillón, M.; Alastuey, A.; Querol, X. Changes in air quality during the lockdown in Barcelona (Spain) one month into the SARS-CoV-2 epidemic. Sci. Total Environ. 2020, 726, 138540. [CrossRef]

15. Nigam, R.; Pandy, K.; Luis, A.; Sengupta, R.; Kotha, M. Positive effects of COVID-19 lockdown on air quality of industrial cities (Ankleshwar and Vapi) of Western India. Sci. Rep. 2021, 11, 4285. [CrossRef] [PubMed]

16. Navinya, C.; Patidar, G.; Phuleria, H.C. Examining effects of the COVID-19 national lockdown on ambient air quality across urban India. Aerosol Air Qual. Res. 2020, 20, 1759-1771. [CrossRef]

17. Sikarwar, A.; Rani, R. Assessing the Immediate Effect of Covid-19 Lockdown on Air Quality: A Case Study of Delhi, India. J. Environ. Geogr. 2020, 13, 27-33. [CrossRef]

18. Singh, R.P.; Chauhan, A. Impact of lockdown on air quality in India during COVID-19 pandemic. Air Qual. Atmos. Health 2020, 13, 921-928. [CrossRef]

19. Zhang, J.; Cui, K.; Wang, Y.F.; Wu, J.L.; Huang, W.S.; Wan, S.; Xu, K. Temporal Variations in the Air Quality Index and the Impact of the COVID-19 Event on Air Quality in Western China. Aerosol Air Qual. Res. 2020, 20, 1552-1568. [CrossRef]

20. Querol, X.; Massagué, J.; Alastuey, A.; Moreno, T.; Gangoiti, G.; Mantilla, E.; Duéguez, J.; Escudero, M.; Monfortf, E.; García-Pando, C.P.; et al. Lessons from the COVID-19 air pollution decrease in Spain: Now what? Sci. Total Environ. 2021, 779, 146380. [CrossRef] [PubMed]

21. Collivignarelli, M.C.; Abbà, A.; Bertanza, G.; Pedrazzani, R.; Ricciardi, P.; Miino, M.C. Lockdown for CoViD-2019 in Milan: What are the effects on air quality? Sci. Total Environ. 2020, 732, 139280. [CrossRef]

22. Mostafa, M.K.; Gamal, G.; Wafiq, A. The impact of COVID 19 on air pollution levels and other environmental indicators-A case study of Egypt. J. Environ. Manag. 2021, 277, 111496. [CrossRef] [PubMed]

23. Singh, V.; Singh, S.; Biswal, A.; Kesarkar, A.P.; Mor, S.; Ravindra, K. Diurnal and temporal changes in air pollution during COVID-19 strict lockdown over different regions of India. Environ. Pollut. 2020, 266, 115368. [CrossRef]

24. Chen, L.-W.A.; Chien, L.-C.; Li, Y.; Lin, G. Nonuniform impacts of COVID-19 lockdown on air quality over the United States. Sci. Total Environ. 2020, 745, 141105. [CrossRef] [PubMed]

25. Islam, S.; Rahman, M.; Tusher, T.R.; Roy, S.; Razi, M.A. Assessing the Relationship between COVID-19, Air Quality, and Meteorological Variables: A Case Study of Dhaka City in Bangladesh. Aerosol Air Qual. Res. 2021, 21, 200609. [CrossRef]

26. Muhammad, S.; Long, X.; Salman, M. COVID-19 pandemic and environmental pollution: A blessing in disguise? Sci. Total Environ. 2020, 728, 138820. [CrossRef] [PubMed]

27. Wang, Q.; Su, M. A preliminary assessment of the impact of COVID-19 on environment-A case study of China. Sci. Total Environ. 2020, 728, 138915. [CrossRef]

28. Saadat, S.; Rawtani, D.; Hussain, C.M. Environmental perspective of COVID-19. Sci. Total Environ. 2020, 728, 138870. [CrossRef]

29. NASA. Airborne Nitrogen Dioxide Plummets over China. 2020. Available online: https:// earthobservatory.nasa.gov/images/14 6362/airborne-nitrogen-dioxide-plummets-over-china (accessed on 28 April 2020).

30. Moher, D.; Liberati, A.; Tetzlaff, J.; Altman, D.G.; The PRISMA Group. Preferred Reporting Items for Systematic Reviews and Meta-Analyses: The PRISMA Statement. PLoS Med. 2009, 6, e1000097. [CrossRef] [PubMed]

31. Naqvi, H.R.; Datta, M.; Mutreja, G.; Siddiqui, M.A.; Naqvi, D.F.; Naqvi, A.R. Improved air quality and associated mortalities in India under COVID-19 lockdown. Environ. Pollut. 2021, 268, 115691. [CrossRef]

32. Mor, S.; Kumar, S.; Singh, T.; Dogra, S.; Pandey, V.; Ravindra, K. Impact of COVID-19 lockdown on air quality in Chandigarh, India: Understanding the emission sources during controlled anthropogenic activities. Chemosphere 2021, 263, 127978. [CrossRef]

33. Eregowda, T.; Chatterjee, P.; Pawar, D.S. Impact of lockdown associated with COVID19 on air quality and emissions from transportation sector: Case study in selected Indian metropolitan cities. Environ. Syst. Decis. 2021, 41, 401-412. [CrossRef]

34. Mahato, S.; Pal, S.; Ghosh, K.G. Effect of lockdown amid COVID-19 pandemic on air quality of the megacity Delhi, India. Sci. Total Environ. 2020, 730, 139086. [CrossRef]

35. Bedi, J.S.; Dhaka, P.; Vijay, D.; Aulakh, R.S.; Gill, J.P.S. Assessment of Air Quality Changes in the Four Metropolitan Cities of India during COVID-19 Pandemic Lockdown. Aerosol Air Qual. Res. 2020, 20, 2062-2070. [CrossRef]

36. Shehzad, K.; Sarfraz, M.; Shah, S.G.M. The impact of COVID-19 as a necessary evil on air pollution in India during the lockdown. Environ. Pollut. 2020, 266, 115080. [CrossRef] [PubMed]

37. Gautam, S. COVID-19: Air pollution remains low as people stay at home. Air Qual. Atmos. Health 2020, 13, 853-857. [CrossRef]

38. Rahman, S.; Azad, A.K.; Hasanuzzaman; Salam, R.; Islam, A.R.M.T.; Rahman, M.; Hoque, M.M.M. How air quality and COVID-19 transmission change under different lockdown scenarios? A case from Dhaka city, Bangladesh. Sci. Total Environ. 2021, 762, 143161. [CrossRef]

39. Mitra, A.; Chaudhuri, T.R.; Mitra, A.; Pramanick, P.; Zaman, S.; Mitra, A.; Zaman, S. Impact of COVID-19 related shutdown on atmospheric carbon dioxide level in the city of Kolkata. Parana J. Sci. Educ. 2020, 6, 84-92.

40. Roy, S.S.; Balling, R.C. Impact of the COVID-19 lockdown on air quality in the Delhi Metropolitan Region. Appl. Geogr. 2021, 128, 102418. [CrossRef]

41. Goel, A. Impact of the COVID-19 Pandemic on the Air Quality in Delhi, India. Nat. Environ. Pollut. Technol. 2020, 19, 1095-1103. [CrossRef] 
42. Chakrabortty, R.; Pal, S.C.; Ghosh, M.; Arabameri, A.; Saha, A.; Roy, P.; Pradhan, B.; Mondal, A.; Ngo, P.; Chowdhuri, I.; et al. Weather indicators and improving air quality in association with COVID-19 pandemic in India. Soft Comput. 2021, $25,1-22$. [CrossRef]

43. Das, M.; Das, A.; Sarkar, R.; Saha, S.; Mandal, A. Examining the impact of lockdown (due to COVID-19) on ambient aerosols $\left(\mathrm{PM}_{2.5}\right)$ : A study on Indo-Gangetic Plain (IGP) Cities, India. Stoch. Environ. Res. Risk Assess. 2021, 35, 1301-1317. [CrossRef] [PubMed]

44. Das, M.; Das, A.; Ghosh, S.; Sarkar, R.; Saha, S. Spatio-temporal concentration of atmospheric particulate matter (PM 2.5$)$ during pandemic: A study on most polluted cities of indo-gangetic plain. Urban Clim. 2021, 35, 100758. [CrossRef]

45. Das, M.; Das, A.; Sarkar, R.; Saha, S.; Mandal, P. Regional scenario of air pollution in lockdown due to COVID-19 pandemic: Evidence from major urban agglomerations of India. Urban Clim. 2021, 37, 100821. [CrossRef]

46. Aman, M.A.; Salman, M.S.; Yunus, A.P. COVID-19 and its impact on environment: Improved pollution levels during the lockdown period-A case from Ahmedabad, India. Remote. Sens. Appl. Soc. Environ. 2020, 20, 100382. [CrossRef]

47. Biswal, A.; Singh, V.; Singh, S.; Kesarkar, A.P.; Ravindra, K.; Sokhi, R.S.; Chipperfield, M.; Dhomse, S.; Pope, R.; Singh, T.; et al. COVID-19 lockdown-induced changes in NO 2 levels across India observed by multi-satellite and surface observations. Atmos. Chem. Phys. 2021, 21, 5235-5251. [CrossRef]

48. Biswas, M.S.; Choudhury, A.D. Impact of COVID-19 Control Measures on Trace Gases $\left(\mathrm{NO}_{2}, \mathrm{HCHO}\right.$ and $\left.\mathrm{SO}_{2}\right)$ and Aerosols over India during Pre-monsoon of 2020. Aerosol Air Qual. Res. 2021, 21, 200306. [CrossRef]

49. Datta, A.; Rahman, H.; Suresh, R. Did the COVID-19 lockdown in Delhi and Kolkata improve the ambient air quality of the two cities? J. Environ. Qual. 2021, 50, 485-493. [CrossRef]

50. Dhaka, S.K.; Kumar, V.; Panwar, V.; Dimri, A.P.; Singh, N.; Patra, P.K.; Matsumi, Y.; Takigawa, M.; Nakayama, T.; Hayashida, S. $\mathrm{PM}_{2.5}$ diminution and haze events over Delhi during the COVID-19 lockdown period: An interplay between the baseline pollution and meteorology. Sci. Rep. 2020, 10, 1-8. [CrossRef]

51. Dutta, A.; Jinsart, W. Air Quality, Atmospheric Variables and Spread of COVID-19 in Delhi (India): An Analysis. Aerosol Air Qual. Res. 2021, 21, 200417. [CrossRef]

52. Siddiqui, A.; Halder, S.; Chauhan, P.; Kumar, P. COVID-19 Pandemic and City-Level Nitrogen Dioxide $\left(\mathrm{NO}_{2}\right)$ Reduction for Urban Centres of India. J. Indian Soc. Remote. Sens. 2020, 48, 1-8. [CrossRef]

53. Sharma, S.; Zhang, M.; Gao, J.; Zhang, H.; Kota, S.H. Effect of restricted emissions during COVID-19 on air quality in India. Sci. Total Environ. 2020, 728, 138878. [CrossRef]

54. Jain, S.; Sharma, T. Social and Travel Lockdown Impact Considering Coronavirus Disease (COVID-19) on Air Quality in Megacities of India: Present Benefits, Future Challenges and Way Forward. Aerosol Air Qual. Res. 2020, 20, 1222-1236. [CrossRef]

55. Kumar, P.; Hama, S.; Omidvarborna, H.; Sharma, A.; Sahani, J.; Abhijith, K.V.; Debele, S.; Zavala-Reyes, J.; Barwise, Y.; Tiwari, A Temporary reduction in fine particulate matter due to 'anthropogenic emissions switch-off'during COVID-19 lockdown in Indian cities. Sustain. Cities Soc. 2020, 62, 102382. [CrossRef] [PubMed]

56. Kumari, P.; Toshniwal, D. Impact of lockdown measures during COVID-19 on air quality-A case study of India. Int. J. Environ. Health Res. 2020, 31, 1-8. [CrossRef]

57. Lal, P.; Kumar, A.; Bharti, S.; Saikia, P.; Adhikari, D.; Khan, M. Lockdown to Contain the COVID-19 Pandemic: An Opportunity to Create a Less Polluted Environment in India. Aerosol Air Qual. Res. 2021, 21, 200229. [CrossRef]

58. Garg, A.; Kumar, A.; Gupta, N.C. Impact of Lockdown on Ambient Air Quality in COVID-19 Affected Hotspot Cities of India: Need to Readdress Air Pollution Mitigation Policies. Environ. Claims J. 2021, 33, 65-76. [CrossRef]

59. Yuan, Q.; Qi, B.; Hu, D.; Wang, J.; Zhang, J.; Yang, H.; Zhang, S.; Liu, L.; Xu, L.; Li, W. Spatiotemporal variations and reduction of air pollutants during the COVID-19 pandemic in a megacity of Yangtze River Delta in China. Sci. Total Environ. 2021, 751, 141820. [CrossRef]

60. Zheng, H.; Kong, S.; Chen, N.; Yan, Y.; Liu, D.; Zhu, B.; Xu, K.; Cao, W.; Ding, Q.; Lan, B.; et al. Significant changes in the chemical compositions and sources of $\mathrm{PM}_{2.5}$ in Wuhan since the city lockdown as COVID-19. Sci. Total Environ. 2020, 739, 140000. [CrossRef]

61. He, G.; Pan, Y.; Tanaka, T. The short-term impacts of COVID-19 lockdown on urban air pollution in China. Nat. Sustain. 2020, 3, 1005-1011. [CrossRef]

62. Ji, J.; Chang, R. Air quality changes and Grey relational analysis of pollutants exceeding standards during the COVID-19 pandemic in Wuhan. Res. Sq. 2020. [CrossRef]

63. Miller, P.; Reesman, C.; Grossman, M.; Nelson, S.; Liu, V.; Wang, P. Marginal warming associated with a COVID-19 quarantine and the implications for disease transmission. Sci. Total Environ. 2021, 780, 146579. [CrossRef]

64. Wang, N.; Xu, J.; Pei, C.; Tang, R.; Zhou, D.; Chen, Y.; Li, M.; Deng, X.; Deng, T.; Huang, X.; et al. Air Quality During COVID-19 Lockdown in the Yangtze River Delta and the Pearl River Delta: Two Different Responsive Mechanisms to Emission Reductions in China. Environ. Sci. Technol. 2021, 55, 5721-5730. [CrossRef]

65. Feng, H.; Ning, E.; Feng, H.; Li, J.; Wang, Q. Impact of COVID-19 on Air Quality in Central and Eastern China. Res. Sq. 2021. [CrossRef]

66. Ming, W.; Zhou, Z.; Ai, H.; Bi, H.; Zhong, Y. COVID-19 and Air Quality: Evidence from China. Emerg. Mark. Finance Trade 2020, 56, 2422-2442. [CrossRef] 
67. Zhang, K.; De Leeuw, G.; Yang, Z.; Chen, X.; Jiao, J. The Impacts of the COVID-19 Lockdown on Air Quality in the Guanzhong Basin, China. Remote. Sens. 2020, 12, 3042. [CrossRef]

68. Filonchyk, M.; Yan, H.; Hurynovich, V.; Wang, Z. Impact of COVID-19 pandemic on air quality changes in Shanghai, China. Environ. Forensics 2021, 1-6. [CrossRef]

69. Silver, B.; He, X.; Arnold, S.R.; Spracklen, D.V. The impact of COVID-19 control measures on air quality in China. Environ. Res. Lett. 2020, 15, 084021. [CrossRef]

70. E Marlier, M.; Xing, J.; Zhu, Y.; Wang, S. Impacts of COVID-19 response actions on air quality in China. Environ. Res. Commun. 2020, 2, 075003. [CrossRef]

71. Xu, K.; Cui, K.; Young, L.-H.; Wang, Y.-F.; Hsieh, Y.-K.; Wan, S.; Zhang, J. Air Quality Index, Indicatory Air Pollutants and Impact of COVID-19 Event on the Air Quality near Central China. Aerosol Air Qual. Res. 2020, 20, 1204-1221. [CrossRef]

72. Tang, R.; Huang, X.; Zhou, D.; Wang, H.; Xu, J.; Ding, A. Global air quality change during the COVID-19 pandemic: Regionally different ozone pollution responses COVID-19. Atmos. Ocean. Sci. Lett. 2021, 14, 100015. [CrossRef]

73. Su, Z.; Duan, Z.; Deng, B.; Liu, Y.; Chen, X. Impact of the COVID-19 Lockdown on Air Quality Trends in Guiyang, Southwestern China. Atmosphere 2021, 12, 422. [CrossRef]

74. Han, Y.; Lam, J.C.; Li, V.O.; Guo, P.; Zhang, Q.; Wang, A.; Crowcroft, J.; Gozes, I.; Fu, J.; Gilani, Z.; et al. Outdoor Air Pollutant Concentration and COVID-19 Infection in Wuhan, China. medRxiv 2020. [CrossRef]

75. Chen, J.; Hu, H.; Wang, F.; Zhang, M.; Zhou, T.; Yuan, S.; Bai, R.; Chen, N.; Xu, K.; Huang, H. Air quality characteristics in Wuhan (China) during the 2020 COVID-19 pandemic. Environ. Res. 2021, 195, 110879. [CrossRef]

76. Filonchyk, M.; Hurynovich, V.; Yan, H. Impact of Covid-19 lockdown on air quality in the Poland, Eastern Europe. Environ. Res. 2021, 198, 110454. [CrossRef] [PubMed]

77. Al-Qaness, M.A.; Fan, H.; Ewees, A.A.; Yousri, D.; Elaziz, M.A. Improved ANFIS model for forecasting Wuhan City Air Quality and analysis COVID-19 lockdown impacts on air quality. Environ. Res. 2021, 194, 110607. [CrossRef] [PubMed]

78. Bao, R.; Zhang, A. Does lockdown reduce air pollution? Evidence from 44 cities in northern China. Sci. Total Environ. 2020, 731, 139052. [CrossRef]

79. Brimblecombe, P.; Lai, Y. Diurnal and weekly patterns of primary pollutants in Beijing under COVID-19 restrictions. Faraday Discuss. 2020, 226, 138-148. [CrossRef] [PubMed]

80. Chang, Y.; Huang, R.; Ge, X.; Huang, X.; Hu, J.; Duan, Y.; Zou, Z.; Liu, X.; Lehmann, M. Puzzling Haze Events in China During the Coronavirus (COVID-19) Shutdown. Geophys. Res. Lett. 2020, 47, 088533. [CrossRef]

81. Chen, Q.X.; Huang, C.L.; Yuan, Y.; Tan, H.P. Influence of COVID-19 event on air quality and their association in Mainland China. Aerosol Air Qual. Res. 2020, 20, 1541-1551. [CrossRef]

82. Diamond, M.S.; Wood, R. Limited Regional Aerosol and Cloud Microphysical Changes Despite Unprecedented Decline in Nitrogen Oxide Pollution During the February 2020 COVID-19 Shutdown in China. Geophys. Res. Lett. 2020, $47,088913$. [CrossRef]

83. Chu, B.; Zhang, S.; Liu, J.; Ma, Q.; He, H. Significant concurrent decrease in $\mathrm{PM}_{2.5}$ and $\mathrm{NO}_{2}$ concentrations in China during COVID-19 epidemic. J. Environ. Sci. 2021, 99, 346-353. [CrossRef]

84. Griffith, S.; Huang, W.; Lin, C.; Chen, Y.; Chang, K.; Lin, T.; Wang, S.; Lin, N. Long-range air pollution transport in East Asia during the first week of the COVID-19 lockdown in China. Sci. Total Environ. 2020, 741, 140214. [CrossRef]

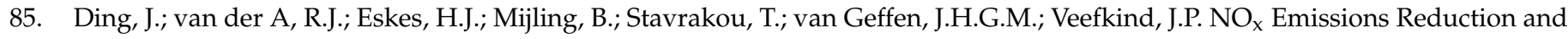
Rebound in China Due to the COVID-19 Crisis. Geophys. Res. Lett. 2020, 47, 089912. [CrossRef]

86. Huang, L.; Liu, Z.; Li, H.; Wang, Y.; Li, Y.; Zhu, Y.; Ooi, M.; An, J.; Shang, Y.; Zhang, D.; et al. The Silver Lining of COVID-19: Estimation of Short-Term Health Impacts Due to Lockdown in the Yangtze River Delta Region, China. GeoHealth 2020, 4, 000272. [CrossRef]

87. Huang, Y.; Zhou, J.L.; Yu, Y.; Mok, W.-C.; Lee, C.; Yam, Y.-S. Uncertainty in the Impact of the COVID-19 Pandemic on Air Quality in Hong Kong, China. Atmosphere 2020, 11, 914. [CrossRef]

88. Le, T.; Wang, Y.; Liu, L.; Yang, J.; Yung, Y.L.; Li, G.; Seinfeld, J.H. Unexpected air pollution with marked emission reductions during the COVID-19 outbreak in China. Science 2020, 369, 702-706. [CrossRef] [PubMed]

89. Li, J.; Yang, H.; Zha, S.; Yu, N.; Liu, X.; Sun, R. Effects of COVID-19 Emergency Response Levels on Air Quality in the Guangdong-Hong Kong-Macao Greater Bay Area, China. Aerosol Air Qual. Res. 2021, 21, 200416. [CrossRef]

90. Li, L.; Li, Q.; Huang, L.; Wang, Q.; Zhu, A.; Xu, J.; Liu, Z.; Li, H.; Shi, L.; Li, R.; et al. Air quality changes during the COVID-19 lockdown over the Yangtze River Delta Region: An insight into the impact of human activity pattern changes on air pollution variation. Sci. Total Environ. 2020, 732, 139282. [CrossRef] [PubMed]

91. Li, Z.; Meng, J.; Zhou, L.; Zhou, R.; Fu, M.; Wang, Y.; Yi, Y.; Song, A.; Guo, Q.; Hou, Z.; et al. Impact of the COVID-19 Event on the Characteristics of Atmospheric Single Particle in the Northern China. Aerosol Air Qual. Res. 2020, 20, 1716-1726. [CrossRef]

92. Lian, X.; Huang, J.; Huang, R.-J.; Liu, C.; Wang, L.; Zhang, T. Impact of city lockdown on the air quality of COVID-19-hit of Wuhan city. Sci. Total Environ. 2020, 742, 140556. [CrossRef]

93. Miyazaki, K.; Bowman, K.; Sekiya, T.; Jiang, Z.; Chen, X.; Eskes, H.; Ru, M.; Zhang, Y.; Shindell, D. Air quality response in China linked to the 2019 novel coronavirus (COVID-19) lockdown. Geophys. Res. Lett. 2020, 47, e2020GL089252. [CrossRef]

94. Kaewrat, J.; Janta, R. Effect of COVID-19 Prevention Measures on Air Quality in Thailand. Aerosol Air Qual. Res. 2021, 21, 200344. [CrossRef] 
95. Stratoulias, D.; Nuthammachot, N. Air quality development during the COVID-19 pandemic over a medium-sized urban area in Thailand. Sci. Total Environ. 2020, 746, 141320. [CrossRef] [PubMed]

96. Masum, M.H.; Pal, S.K. Statistical evaluation of selected air quality parameters influenced by COVID-19 lockdown. Glob. J. Environ. Sci. Manag. 2020, 6, 85-94.

97. Islam, S.; Tusher, T.R.; Roy, S.; Rahman, M. Impacts of nationwide lockdown due to COVID-19 outbreak on air quality in Bangladesh: A spatiotemporal analysis. Air Qual. Atmos. Health 2021, 14, 351-363. [CrossRef]

98. Roy, S.; Chowdhury, N.; Bhuyan, M.M.M. COVID-19 Induced Lockdown Consequences on Air Quality and Economy-A Case Study of Bangladesh. J. Environ. Pollut. Hum. Health 2020, 8, 55-68.

99. Kanniah, K.D.; Zaman, N.A.F.K.; Kaskaoutis, D.G.; Latif, M.T. COVID-19's impact on the atmospheric environment in the Southeast Asia region. Sci. Total Environ. 2020, 736, 139658, Erratum in 2020, 745, 142200. [CrossRef] [PubMed]

100. Suhaimi, N.F.; Jalaludin, J.; Latif, M.T. Demystifying a Possible Relationship between COVID-19, Air Quality and Meteorological Factors: Evidence from Kuala Lumpur, Malaysia. Aerosol Air Qual. Res. 2020, 20, 1520-1529. [CrossRef]

101. Li, J.; Tartarini, F. Changes in Air Quality during the COVID-19 Lockdown in Singapore and associations with Human Mobility Trends. Aerosol Air Qual. Res. 2020, 20, 1748-1758. [CrossRef]

102. Seo, J.; Jeon, H.; Sung, U.; Sohn, J.-R. Impact of the COVID-19 Outbreak on Air Quality in Korea. Atmosphere 2020, $11,1137$. [CrossRef]

103. Han, B.-S.; Park, K.; Kwak, K.-H.; Park, S.-B.; Jin, H.-G.; Moon, S.; Kim, J.-W.; Baik, J.-J. Air quality change in Seoul, South Korea under COVID-19 social distancing: Focusing on $\mathrm{PM}_{2.5}$. Int. J. Environ. Res. Public Health 2020, 17, 6208. [CrossRef]

104. Ju, M.J.; Oh, J.; Choi, Y.-H. Changes in air pollution levels after COVID-19 outbreak in Korea. Sci. Total Environ. 2021, 750, 141521. [CrossRef]

105. Agami, S. Impact of COVID-19 on Air Quality in Israel. arXiv 2020, arXiv:2007.06501. Available online: https://arxiv.org/abs/20 07.06501v1 (accessed on 14 April 2021).

106. Broomandi, P.; Karaca, F.; Nikfal, A.; Jahanbakhshi, A.; Tamjidi, M.; Kim, J.R. Impact of COVID-19 Event on the Air Quality in Iran. Aerosol Air Qual. Res. 2020, 20, 1793-1804. [CrossRef]

107. Mehmood, K.; Bao, Y.; Petropoulos, G.P.; Abbas, R.; Abrar, M.M.; Mustafa, A.; Soban, A.; Saud, S.; Ahmad, M.; Fahad, S. Investigating connections between COVID-19 pandemic, air pollution and community interventions for Pakistan employing geo-information technologies. Chemosphere 2021, 272, 129809. [CrossRef]

108. Bacak, T.; Dursun, Ş.; Toros, H. The Effect of COVID-19 Outbreak on Air Quality of Istanbul City Centre. 2020. Available online: https://www.researchgate.net/profile/Tugce-Bacak/publication/346059005_The_Effect_of_COVID-19_outbreak_on_ Air_Quality_of_Istanbul_city_centre/links/5fb9307d458515b7975cc203/The-Effect-of-COVID-19-outbreak-on-Air-Quality-ofIstanbul-city-centre.pdf (accessed on 25 May 2021).

109. Şahin, A. The Effects of COVID-19 Measures on Air Pollutant Concentrations at Urban and Traffic Sites in Istanbul. Aerosol Air Qual. Res. 2020, 20, 1874-1885. [CrossRef]

110. Nguyen, T.P.M.; Bui, T.H.; Nguyen, M.K.; Nguyen, T.H.; Pham, H.L. Impact of Covid-19 partial lockdown on $\mathrm{PM}_{2.5}, \mathrm{SO}_{2}, \mathrm{NO}_{2}$, $\mathrm{O}_{3}$, and trace elements in $\mathrm{PM}_{2.5}$ in Hanoi, Vietnam. Environ. Sci. Pollut. Res. 2021, 1-11. [CrossRef]

111. Kerimray, A.; Baimatova, N.; Ibragimova, O.; Bukenov, B.; Kenessov, B.; Plotitsyn, P.; Karaca, F. Assessing air quality changes in large cities during COVID-19 lockdowns: The impacts of traffic-free urban conditions in Almaty, Kazakhstan. Sci. Total Environ. 2020, 730, 139179. [CrossRef]

112. Anil, I.; Alagha, O. The impact of COVID-19 lockdown on the air quality of Eastern Province, Saudi Arabia. Air Qual. Atmos. Health 2021, 14, 117-128. [CrossRef]

113. Faridi, S.; Yousefian, F.; Niazi, S.; Ghalhari, M.R.; Hassanvand, M.S.; Naddafi, K. Impact of SARS-CoV-2 on ambient air particulate matter in Tehran. Aerosol Air Qual. Res. 2020, 20, 1805-1811. [CrossRef]

114. Anderson, B.; Dirks, K. A Preliminary Analysis of Changes in Outdoor Air Quality in the City of Southampton during the 2020 COVID-19 Outbreak to Date: A Response to DEFRA's Call for Evidence 1 on Estimation of Changes in Air Pollution Emissions, Concentrations and Exposure during the COVID-19 Outbreak in the UK. 2020. Available online: https:/ / cfsotago.github.io/ airQual/sccAirQualExplore_covidLockdown2020.html (accessed on 12 May 2021).

115. Lee, J.D.; Drysdale, W.S.; Finch, D.P.; Wilde, S.E.; Palmer, P.I. UK surface $\mathrm{NO}_{2}$ levels dropped by $42 \%$ during the COVID-19 lockdown: Impact on surface $\mathrm{O}_{3}$. Atmos. Chem. Phys. Discuss. 2020, 20, 15743-15759. [CrossRef]

116. Jephcote, C.; Hansell, A.L.; Adams, K.; Gulliver, J. Changes in air quality during COVID-19 'lockdown' in the United Kingdom. Environ. Pollut. 2021, 272, 116011. [CrossRef]

117. Sannino, A.; D’Emilio, M.; Castellano, P.; Amoruso, S.; Boselli, A. Analysis of Air Quality during the COVID-19 Pandemic Lockdown in Naples (Italy). Aerosol Air Qual. Res. 2021, 21, 200381. [CrossRef]

118. Travaglio, M.; Yu, Y.; Popovic, R.; Selley, L.; Leal, N.S.; Martins, L.M. Links between air pollution and COVID-19 in England. Environ. Pollut. 2021, 268, 115859. [CrossRef]

119. Ropkins, K.; Tate, J.E. Early observations on the impact of the COVID-19 lockdown on air quality trends across the UK. Sci. Total Environ. 2021, 754, 142374. [CrossRef] [PubMed]

120. Wyche, K.; Nichols, M.; Parfitt, H.; Beckett, P.; Gregg, D.; Smallbone, K.; Monks, P. Changes in ambient air quality and atmospheric composition and reactivity in the South East of the UK as a result of the COVID-19 lockdown. Sci. Total Environ. 2021, 755, 142526. [CrossRef] 
121. Higham, J.; Ramírez, C.A.; Green, M.; Morse, A.P. UK COVID-19 lockdown: 100 days of air pollution reduction? Air Qual. Atmos. Health 2021, 14, 325-332. [CrossRef]

122. A Potts, D.; A Marais, E.; Boesch, H.; Pope, R.J.; Lee, J.; Drysdale, W.; Chipperfield, M.P.; Kerridge, B.; Siddans, R.; Moore, D.P.; et al. Diagnosing air quality changes in the UK during the COVID-19 lockdown using TROPOMI and GEOS-Chem. Environ. Res. Lett. 2021, 16, 054031. [CrossRef]

123. Briz-Redón, Á.; Belenguer-Sapiña, C.; Serrano-Aroca, Á. Changes in air pollution during COVID-19 lockdown in Spain: A multi-city study. J. Environ. Sci. 2021, 101, 16-26. [CrossRef] [PubMed]

124. Mesas-Carrascosa, F.-J.; Porras, F.P.; Triviño-Tarradas, P.; García-Ferrer, A.; Meroño-Larriva, J. Effect of Lockdown Measures on Atmospheric Nitrogen Dioxide during SARS-CoV-2 in Spain. Remote. Sens. 2020, 12, 2210. [CrossRef]

125. Donzelli, G.; Cioni, L.; Cancellieri, M.; Llopis-Morales, A.; Morales-Suárez-Varela, M. Relations between Air Quality and Covid-19 Lockdown Measures in Valencia, Spain. Int. J. Environ. Res. Public Health 2021, 18, 2296. [CrossRef]

126. Petetin, H.; Bowdalo, D.; Soret, A.; Guevara, M.; Jorba, O.; Serradell, K.; García-Pando, C.P. Meteorology-normalized impact of the COVID-19 lockdown upon $\mathrm{NO}_{2}$ pollution in Spain. Atmos. Chem. Phys. Discuss. 2020, 20, 11119-11141. [CrossRef]

127. Baldasano, J.M. COVID-19 lockdown effects on air quality by $\mathrm{NO}_{2}$ in the cities of Barcelona and Madrid (Spain). Sci. Total Environ. 2020, 741, 140353. [CrossRef]

128. Bassani, C.; Vichi, F.; Esposito, G.; Montagnoli, M.; Giusto, M.; Ianniello, A. Nitrogen dioxide reductions from satellite and surface observations during COVID-19 mitigation in Rome (Italy). Environ. Sci. Pollut. Res. 2021, 28, 22981-23004. [CrossRef]

129. Coker, E.S.; Cavalli, L.; Fabrizi, E.; Guastella, G.; Lippo, E.; Parisi, M.L.; Pontarollo, N.; Rizzati, M.; Varacca, A.; Vergalli, S. The Effects of Air Pollution on COVID-19 Related Mortality in Northern Italy. Environ. Resour. Econ. 2020, 76, 611-634. [CrossRef] [PubMed]

130. Cameletti, M. The Effect of Corona Virus Lockdown on Air Pollution: Evidence from the City of Brescia in Lombardia Region (Italy). Atmos. Environ. 2020, 239, 117794. [CrossRef] [PubMed]

131. Albrecht, L.; Czarnecki, P.; Sakelaris, B. Investigating the Relationship between Air Quality and COVID-19 Transmission. J. data Sci. JDS 2021, 19, 485-497. [CrossRef]

132. Granella, F.; Reis, L.A.; Bosetti, V.; Tavoni, M. COVID-19 lockdown only partially alleviates health impacts of air pollution in Northern Italy. Environ. Res. Lett. 2021, 16, 035012. Available online: https:/ / iopscience.iop.org/article/10.1088/1748-9326/abd3 d2/meta (accessed on 19 May 2021). [CrossRef]

133. Dursun, S.; Sagdic, M.; Toros, H. The impact of COVID-19 measures on air quality in Turkey. Environ. Forensics 2021, $22,1-13$. [CrossRef]

134. Aydın, S.; Nakiyingi, B.A.; Esmen, C.; Güneysu, S.; Ejjada, M. Environmental impact of coronavirus (COVID-19) from Turkish perceptive. Environ. Dev. Sustain. 2021, 23, 7573-7580. [CrossRef]

135. Kaskun, S. The effect of COVID-19 pandemic on air quality caused by tra c in Istanbul. Res. Sq. 2020, 1-24. [CrossRef]

136. Sbai, S.E.; Mejjad, N.; Norelyaqine, A.; Bentayeb, F. Air quality change during the COVID-19 pandemic lockdown over the Auvergne-Rhône-Alpes region, France. Air Qual. Atmos. Health 2021, 14, 617-628. [CrossRef]

137. Ginzburg, A.S.; Semenov, V.A.; Semutnikova, E.G.; Aleshina, M.A.; Zakharova, P.V.; Lezina, E.A. Impact of COVID-19 Lockdown on Air Quality in Moscow. Dokl. Earth Sci. 2020, 495, 862-866. [CrossRef]

138. Burns, J.; Hoffmann, S.; Kurz, C.; Laxy, M.; Polus, S.; Rehfuess, E. COVID-19 mitigation measures and nitrogen dioxide-A quasi-experimental study of air quality in Munich, Germany. Atmos. Environ. 2021, 246, 118089. [CrossRef]

139. Dimovska, M.; Gjorgjev, D. The Effects of COVID-19 Lockdown on Air Quality in Macedonia. Open Access Maced. J. Med Sci. 2020, 8, 353-362. [CrossRef]

140. Gama, C.; Relvas, H.; Lopes, M.; Monteiro, A. The impact of COVID-19 on air quality levels in Portugal: A way to assess traffic contribution. Environ. Res. 2021, 193, 110515. [CrossRef] [PubMed]

141. Velders, G.J.; Willers, S.M.; Wesseling, J.; Elshout, S.V.D.; van der Swaluw, E.; Mooibroek, D.; van Ratingen, S. Improvements in air quality in the Netherlands during the corona lockdown based on observations and model simulations. Atmos. Environ. 2021, 247, 118158. [CrossRef]

142. Dragic, N.; Bijelovic, S.; Jevtic, M.; Velicki, R.; Radic, I. Short-term health effects of air quality changes during the COVID-19 pandemic in the City of Novi Sad, the Republic of Serbia. Int. J. Occup. Med. Environ. Health 2021, 34, 1-15. [CrossRef] [PubMed]

143. Bourdrel, T.; Annesi-Maesano, I.; Alahmad, B.; Maesano, C.N.; Bind, M.-A. The impact of outdoor air pollution on COVID-19: A review of evidence from in vitro, animal, and human studies. Eur. Respir. Rev. 2021, 30, 200242. [CrossRef] [PubMed]

144. Menut, L.; Bessagnet, B.; Siour, G.; Mailler, S.; Pennel, R.; Cholakian, A. Impact of lockdown measures to combat Covid-19 on air quality over western Europe. Sci. Total Environ. 2020, 741, 140426. [CrossRef]

145. Deroubaix, A.; Brasseur, G.; Gaubert, B.; Labuhn, I.; Menut, L.; Siour, G.; Tuccella, P. Response of surface ozone concentration to emission reduction and meteorology during the COVID-19 lockdown in Europe. Authorea Preprints 2020, 28. [CrossRef]

146. Goldberg, D.L.; Anenberg, S.C.; Griffin, D.; McLinden, C.A.; Lu, Z.; Streets, D.G. Disentangling the Impact of the COVID-19 Lockdowns on Urban $\mathrm{NO}_{2}$ From Natural Variability. Geophys. Res. Lett. 2020, 47, e2020g1089269. [CrossRef] [PubMed]

147. Pan, S.; Jung, J.; Li, Z.; Hou, X.; Roy, A.; Choi, Y.; Gao, H. Air Quality Implications of COVID-19 in California. Sustainability 2020, 12, 7067. [CrossRef]

148. Takagi, H.; Kuno, T.; Yokoyama, Y.; Ueyama, H.; Matsushiro, T.; Hari, Y.; Ando, T. Air Quality and COVID-19 Prevalence/Fatality. medRxiv 2020. [CrossRef] 
149. Berman, J.D.; Ebisu, K. Changes in U.S. air pollution during the COVID-19 pandemic. Sci. Total Environ. 2020, $739,139864$. [CrossRef]

150. Jiang, Z.; Shi, H.; Zhao, B.; Gu, Y.; Zhu, Y.; Miyazaki, K.; Lu, X.; Zhang, Y.; Bowman, K.; Sekiya, T.; et al. Modeling the Impact of COVID-19 on Air Quality in Southern California: Implications for Future Control Policies. Atmos. Chem. Phys. Discuss. 2020, 21, 8693-8708. [CrossRef]

151. Zangari, S.; Hill, D.T.; Charette, A.T.; Mirowsky, J.E. Air quality changes in New York City during the COVID-19 pandemic. Sci. Total Environ. 2020, 742, 140496. [CrossRef] [PubMed]

152. Liu, Q.; Harris, J.T.; Chiu, L.S.; Sun, D.; Houser, P.R.; Yu, M.; Duffy, D.Q.; Little, M.M.; Yang, C. Spatiotemporal impacts of COVID-19 on air pollution in California, USA. Sci. Total Environ. 2021, 750, 141592. [CrossRef]

153. Adams, M.D. Air pollution in Ontario, Canada during the COVID-19 State of Emergency. Sci. Total Environ. 2020, $742,140516$. [CrossRef]

154. Hernández-Paniagua, I.Y.; Valdez, S.I.; Almanza, V.; Rivera-Cárdenas, C.; Grutter, M.; Stremme, W.; García-Reynoso, A.; RuizSuárez, L.G. Impact of the COVID-19 Lockdown on Air Quality and Resulting Public Health Benefits in the Mexico City Metropolitan Area. Front. Public Health 2021, 9, 642630. [CrossRef]

155. Zalakeviciute, R.; Vasquez, R.; Bayas, D.; Buenano, A.; Mejia, D.; Zegarra, R.; Diaz, V.; Lamb, B. Drastic Improvements in Air Quality in Ecuador during the COVID-19 Outbreak. Aerosol Air Qual. Res. 2020, 20, 1783-1792. [CrossRef]

156. Nakada, L.Y.K.; Urban, R.C. COVID-19 pandemic: Impacts on the air quality during the partial lockdown in São Paulo state, Brazil. Sci. Total Environ. 2020, 730, 139087. [CrossRef]

157. Siciliano, B.; Carvalho, G.; da Silva, C.M.; Arbilla, G. The Impact of COVID-19 Partial Lockdown on Primary Pollutant Concentrations in the Atmosphere of Rio de Janeiro and São Paulo Megacities (Brazil). Bull. Environ. Contam. Toxicol. 2020, 105, 2-8. [CrossRef] [PubMed]

158. Zambrano-Monserrate, M.A.; Ruano, M.A. Has air quality improved in Ecuador during the COVID-19 pandemic? A parametric analysis. Air Qual. Atmos. Health 2020, 13, 929-938. [CrossRef]

159. Cazorla, M.; Herrera, E.; Palomeque, E.; Saud, J. What the COVID-19 lockdown revealed about photochemistry and ozone production in Quito, Ecuador. Atmos. Pollut. Res. 2021, 12, 124-133. [CrossRef]

160. Mendez-Espinosa, J.F.; Rojas, N.Y.; Vargas, J.; Pachón, J.E.; Belalcazar, L.C.; Ramírez, O. Air quality variations in Northern South America during the COVID-19 lockdown. Sci. Total Environ. 2020, 749, 141621. [CrossRef] [PubMed]

161. Kutralam-Muniasamy, G.; Pérez-Guevara, F.; Roy, P.D.; Elizalde-Martínez, I.; Shruti, V. Impacts of the COVID-19 lockdown on air quality and its association with human mortality trends in megapolis Mexico City. Air Qual. Atmos. Health 2021, 14, 553-562. [CrossRef]

162. El-Magd, I.A.; Zanaty, N. Impacts of short-term lockdown during COVID-19 on air quality in Egypt. Egypt. J. Remote. Sens. Space Sci. 2020. [CrossRef]

163. Sekmoudi, I.; Khomsi, K.; Faieq, S.; Idrissi, L. Covid-19 lockdown improves air quality in Morocco. arXiv 2020, arXiv:2007.05417. Available online: https:/ /arxiv.org/abs/2007.05417v1 (accessed on 1 May 2021).

164. Khomsi, K.; Najmi, H.; Amghar, H.; Chelhaoui, Y.; Souhaili, Z. COVID-19 national lockdown in Morocco: Impacts on air quality and public health. One Health 2020, 11, 100200. [CrossRef]

165. Meji, M.A.; Dennison, M.S.; Mobisha, M. Effect of COVID-19 Induced Lockdown on Air Quality in Kampala. i-Manag. J. Future Eng. Technol. 2020, 16, 43. Available online: https://www.researchgate.net/profile/Abisha-Meji-Milon/publication/346631 417_EFFECT_OF_COVID-19_INDUCED_LOCKDOWN_ON_AIR_QUALITY_IN_KAMPALA/links/5fca620892851c00f84d5 5b9/EFFECT-OF-COVID-19-INDUCED-LOCKDOWN-ON-AIR-QUALITY-IN-KAMPALA.pdf (accessed on 19 May 2021). [CrossRef]

166. Fuwape, I.A.; Okpalaonwuka, C.T.; Ogunjo, S.T. Impact of COVID -19 pandemic lockdown on distribution of inorganic pollutants in selected cities of Nigeria. Air Qual. Atmos. Health 2021, 14, 149-155. [CrossRef]

167. Wilson, A.D. Electronic-nose applications in forensic science and for analysis of volatile biomarkers in the human breath. J. Forensic Sci. Criminol. 2014, 1, 1-21.

168. Brooks, W.A.; Goswami, D.; Rahman, M.; Nahar, K.; Fry, A.M.; Balish, A.; Iftekharuddin, N.; Azim, T.; Xu, X.; Klimov, A.; et al. Influenza is a major contributor to childhood pneumonia in a tropical developing country. Pediatric Infect. Dis. J. 2010, 29, 216-221. [CrossRef]

169. Maji, K.J.; Dikshit, A.K.; Arora, M.; Deshpande, A. Estimating premature mortality attributable to $\mathrm{PM}_{2.5}$ exposure and benefit of air pollution control policies in China for 2020. Sci. Total Environ. 2018, 612, 683-693. [CrossRef] [PubMed]

170. Martelletti, L.; Martelletti, P. Air pollution and the novel Covid-19 disease: A putative disease risk factor. SN Compr. Clin. Med. 2020, 15, 1-5. [CrossRef] [PubMed]

171. Ogen, Y. Assessing nitrogen dioxide $\left(\mathrm{NO}_{2}\right)$ levels as a contributing factor to coronavirus (COVID-19) fatality. Sci. Total Environ. 2020, 726, 138605. [CrossRef] [PubMed]

172. Zhu, L.; She, Z.-G.; Cheng, X.; Qin, J.-J.; Zhang, X.-J.; Cai, J.; Lei, F.; Wang, H.; Xie, J.; Wang, W.; et al. Association of Blood Glucose Control and Outcomes in Patients with COVID-19 and Pre-existing Type 2 Diabetes. Cell Metab. 2020, 31, 1068-1077. [CrossRef] [PubMed]

173. Fattorini, D.; Regoli, F. Role of the chronic air pollution levels in the Covid-19 outbreak risk in Italy. Environ. Pollut. 2020, 264, 114732. [CrossRef] 
174. Huang, C.; Wang, Y.; Li, X.; Ren, L.; Zhao, J.; Hu, Y.; Zhang, L.; Fan, G.; Xu, J.; Gu, X.; et al. Clinical features of patients infected with 2019 novel coronavirus in Wuhan, China. Lancet 2020, 395, 497-506. [CrossRef]

175. Intergovernmental Panel on Climate Change (IPCC). Contribution of Working Group III to the Fourth Assessment Report of the Intergovernmental Panel on Climate Change; Metz, O.R.D.B., Bosch, P.R., Cambridge, L.A.M., Eds.; Cambridge University Press: Cambridge, UK, 2007. 